\title{
Three Selected Edible Crops of the Genus Momordica as Potential Sources of Phytochemicals: Biochemical, Nutritional, and Medicinal Values
}

\section{OPEN ACCESS}

Edited by:

Patrícia Mendonca Rijo, Universidade Lusófona, Portugal

Reviewed by: Liu Jieqing,

Huaqiao University, China Muthu Thiruvengadam, Konkuk University, South Korea

*Correspondence: Bahare Salehi bahar.saheli007@gmail.com Ahmad Faizal Abdull Razis madfaizal@upm.edu.my Javad Sharifi-Rad javad.sharifirad@gmail.com

Specialty section: This article was submitted to

Ethnopharmacology,

a section of the journal

Frontiers in Pharmacology

Received: 03 November 2020 Accepted: 26 April 2021 Published: 13 May 2021

Citation: Muronga M, Quispe C, Tshikhudo PP, Msagati TAM, Mudau FN, Martorell M, Salehi B, Abdull Razis AF, Sunusi U, Kamal RM and Sharifi-Rad J (2021) Three Selected Edible Crops of the

Genus Momordica as Potential Sources of Phytochemicals: Biochemical, Nutritional, and Medicinal Values.

Front. Pharmacol. 12:625546. doi: 10.3389/fphar.2021.625546
Mashudu Muronga ${ }^{1}$, Cristina Quispe ${ }^{2}$, Phumudzo P. Tshikhudo ${ }^{3}$, Titus A. M Msagati ${ }^{4}$ Fhatuwani N. Mudau ${ }^{1,5}$, Miquel Martorell ${ }^{6,7}$, Bahare Salehi ${ }^{8 *}$, Ahmad Faizal Abdull Razis ${ }^{9,10 *}$, Usman Sunusi ${ }^{10,11}$, Ramla Muhammad Kamal ${ }^{10,12}$ and Javad Sharifi-Rad ${ }^{13,14 *}$

${ }^{1}$ Department of Agriculture and Animal Health, College of Agriculture and Environmental Sciences, University of South Africa, Florida, South Africa, ${ }^{2}$ Facultad de Ciencias De La Salud, Universidad Arturo Prat, lquique, Chile, ${ }^{3}$ Pest Risk Analysis, Directorate Plant Health, Department of Agriculture, Land Reform and Rural Development, Pretoria, South Africa, ${ }^{4}$ Nanotechnology and Water Sustainability Unit, College of Science Engineering and Technology, University of South Africa, Science Campus, Florida, South Africa, ${ }^{5}$ School of Agriculture, Earth and Environmental Sciences, University of KwaZulu-Natal, Pietermaritzburg, South Africa, ${ }^{6}$ Department of Nutrition and Dietetics, Faculty of Pharmacy, and Centre for Healthy Living, University of Concepción, Concepción, Chile, ${ }^{7}$ Universidad de Concepción, Unidad de Desarrollo Tecnológico, UDT, Concepción, Chile, ${ }^{8}$ Medical Ethics and Law Research Center, Shahid Beheshti University of Medical Sciences, Tehran, Iran, ${ }^{9}$ Department of Food Science, Faculty of Food Science and Technology, Universiti Putra Malaysia, Selangor, Malaysia, ${ }^{10}$ Natural Medicines and Products Research Laboratory, Institute of Bioscience, Universiti Putra Malaysia, Selangor, Malaysia, ${ }^{11}$ Department of Biochemistry, Bayero University Kano P M B, Kano, Nigeria, ${ }^{12}$ Department of Pharmacology, Federal University Dutse, Dutse, Nigeria,

${ }^{13}$ Phytochemistry Research Center, Shahid Beheshti University of Medical Sciences, Tehran, Iran, ${ }^{14}$ Facultad de Medicina, Universidad Del Azuay, Cuenca, Ecuador

Momordica species (Family Cucurbitaceae) are cultivated throughout the world for their edible fruits, leaves, shoots and seeds. Among the species of the genus Momordica, there are three selected species that are used as vegetable, and for medicinal purposes, Momordica charantia L (Bitter melon), Momordica foetida Schumach (Bitter cucumber) and Momordica balsamina $L$ (African pumpkin). The fruits and leaves of these Momordica species are rich in primary and secondary metabolites such as proteins, fibers, minerals (calcium, iron, magnesium, zinc), $\beta$-carotene, foliate, ascorbic acid, among others. The extracts from Momordica species are used for the treatment of a variety of diseases and ailments in traditional medicine. Momordica species extracts are reputed to possess antidiabetic, anti-microbial, anthelmintic bioactivity, abortifacient, anti-bacterial, anti-viral, and play chemo-preventive functions. In this review we summarize the biochemical, nutritional, and medicinal values of three Momordica species (M. charantia, M. foetida and $M$. balsamina) as promising and innovative sources of natural bioactive compounds for future pharmaceutical usage.

Keywords: momordica, anti-microbial, photochemical, secondary metabolites, inter alia 


\section{INTRODUCTION}

Momordica charantia L. (Bitter melon), Momordica foetida Schumach. (Bitter cucumber), Momordica balsamina L. (African pumpkin) are widely cultivated and they belong to the family Cucurbitaceae (Daniel et al., 2014). In some African countries; fruits, leafy shoots and the ripe seeds from these three species are harvested for consumption as vegetable, spices and leaves are mixed with water and consumed as beverages (Cantwell et al., 1996). Momordica species (spp.) are annual crops but can be regarded as perennial crop due to their performance during the season (Krawinkel and Keding, 2006; Tan et al., 2008; Costa et al., 2010; Chen et al., 2011; Abegunde et al., 2018). These crop species are mostly adapted to areas of minimum annual average rainfall such as those that receive an average of $400 \mathrm{~mm}$ as well as those with mild and frost-free winters (Tokhtar and Doan, 2014). Momordica spp. require a minimum temperature of $18^{\circ} \mathrm{C}$ during emergence and germination and during vegetative stage and flowering and an optimal temperature ranging between 24 and $27^{\circ} \mathrm{C}$ (Tan et al., 2008). Some researchers have stated that the crops adapt and perform well in deep and well-drained sandy loam and slit loam soils which are rich in organic matter and adapt well in soils with optimum soil $\mathrm{pH}$ ranging from 4.3 to 8.0 (Tan C. et al., 2015). However, they can adapt to alkaline soils with up to $\mathrm{pH}$ of 8.0 (Grover and Yadav, 2004; Harinantenaina et al., 2006; Tan et al., 2008). Momordica spp. are open-pollinated and consist of separate male and female flowers on the same plant (Palada and Chang, 2003). Flowering of Momordica species begins a month after planting until reaching dormancy. The fruits are orange in color and soft when ripe with black seeds (Bakare et al., 2010). The local South African indigenous traditional people have been using Momordica spp. as culinary species or enhance bitterness of the meat and of vegetables (Madala et al., 2014). However, studies on the trend of food consumption for rural residents in developing countries have often focused relatively on the economic factors such as prices, income, and market development Jia et al. (2017), and have rarely covered social and psychological influences.

Normally, Momordica spp. are consumed as vegetables and as nutrient supplements in Asia, Africa and South America and they are also used as medicinal herbs (Tan et al., 2008; Madala et al., 2014; Jia et al., 2017; Islam and Jalaluddin, 2019). Different parts of Momordica spp. are rich in both primary and secondary metabolites. The primary metabolites that are derived from Momordica spp. include sugars, proteins and chlorophyll (Hassan and Umar, 2006; Daniel et al., 2014), while secondary metabolites are alkaloids, flavonoids, tannins (Roškar and Lušin, 2012; Mada et al., 2013; Madala et al., 2016; Mostafa et al., 2018). Momordica spp. are good a source of phenolic compounds, gallic acid, gentisic acid (2,5-dihydroxyl benzoic acid), catechins, chlorogenic acid and epicatechin (Abegunde et al., 2018).

Generally, extracts from Momordica spp. are useful for the treatment of various diseases and many other ailments due to the several biological activities exerted such as anti-diabetic Tan et al. (2008), Madala et al. (2014), Jia et al. (2017), Islam and Jalaluddin (2019), Perera et al. (2021), Venugopal and Dhanasekaran (2021), anti-oxidant Acquaviva et al. (2013), Ozusaglam and Karakoca
(2013), Huang et al. (2020), Perumal et al. (2021), anti-microbial (Kumar et al. (2009), Patel et al. (2010), Gupta et al. (2011), antibacterial (Koneri et al. (2006), Orhan et al. (2010), Leelaprakash et al. (2011), Puškárová et al. (2017), Chen et al. (2019), Islam and Jalaluddin (2019), Khadijeh et al. (2019), anti-viral Orhan et al. (2010), Santhosh Kumar et al. (2020), anti-fungal Santos et al. (2012), anthelmintic Beloin et al. (2005), Jia et al. (2017), insecticidal Pari et al. (2020), antiglycation Chen et al. (2011), anti-inflammatory Chen et al. (2019), Khadijeh et al. (2019), Perera et al. (2021), Venugopal and Dhanasekaran (2021), antithrombotic Patil and Rathod (2020), anti-allergic Asna et al. (2020), hepatoprotective Ramalhete et al. (2011), estrogenic Badhwar et al. (2020), hypolipidemic effect Aeri and Raj (2020), anti-carcinogenic Kesari et al. (2020), anti-proliferative Yue et al. (2020), anti-mutagenic Rolnik and Olas (2020), and chemo-preventive activities (Gupta, 2020).

Momordica spp. have been reported to have inhibitory effects against diabetes, cancer, and cardiovascular diseases in animal and humans (Trakoon-osot et al., 2013; Fongod et al., 2014; Ingle et al., 2017; Jabeen and Khanum, 2017; Perera et al., 2021). Some studies shows that the bioactivity effectiveness in lowering of blood sugar (Huang et al., 2008; Rahmatullah et al., 2012; Balouiri et al., 2016; Anjamma and Bhavani, 2018), in controlling eye disorders and enhancing eyesight due to the presence of $\beta$-carotene (Ludidi et al., 2019). In addition, some studies have suggested that Momordica spp. are used to treat gastrointestinal parasitic disease (Grover and Yadav, 2004), diarrhea, bleeding of gums Abidemi (2013), piles and hemorrhoids Lii et al. (2009), respiratory problems Leung et al. (2009) and skin infections (Kumar and Bhowmik, 2010). The anti-viral and anti-leukemic activities of extract from M. balsamina against liver cancer, leukemia, melanoma and solid sarcomas have also been reported (Lu et al., 2011; Aparicio et al., 2021).

Momordica spp. have flavonoids with anti-microbial activities (Orhan et al., 2010) and Momordica leaves extracts have shown anti-bacterial activities against Staphylococcus aureus, Salmonella typhii, Escherichia coli, Klebsiella pneumoniae, Bacillus subtilis, Pseudomonas sp. and Entamoeba histolytica (Tansey et al., 2004; Froelich et al., 2007; Ghosh, 2014; Balouiri et al., 2016) and the fruit extract possesses anti-microbial activity against Helicobacter pylori (Mwambete, 2009).

The use of the plant extracts of Momordica spp. to fully explored their effectiveness, may lead to new drug discovery or advance the use of indigenous herbal medicines for orthodox treatment of certain diseases (Rahmatullah et al., 2012). The aim of this review was to discuss the biochemical, nutritional, and medicinal values of three Momordica spp. (M. charantia, M. foetida and M. balsamina) as promising and innovative sources of natural bioactive compounds for future pharmaceutical usage.

\section{METHODOLOGY}

\section{Type of Review}

The systematic review method involved six steps: 1) scoping; 2) planning; 3) search process and identification of articles; 4) Screening of articles; 5) assessment of relevancy and 6) 


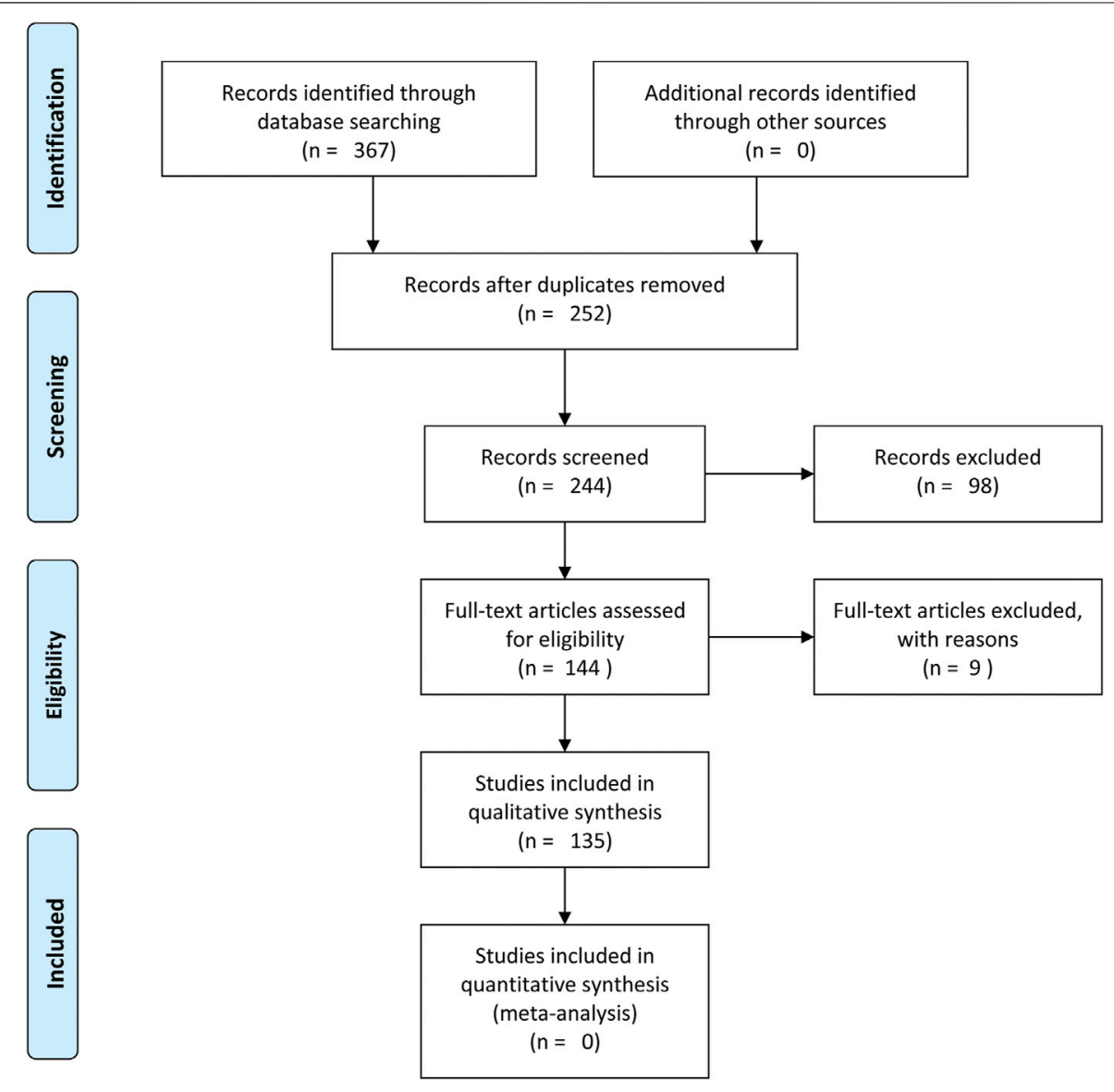

FIGURE 1 | PRISMA flow diagram.

Presentation and interpretation of the results. As a rigorous and unbiased method of evaluating and screening the literature attributed to its replicability and exhaustiveness, it is a method of choice suitable for summarizing the current literature on the three Momordica spp (M. charantia, M. foetida and $M$. balsamina).

\section{Literature Sources and Searching Procedure}

The search was conducted from six electronic database (Web of Science, Science.gov, Science Direct, Google Scholar, Scopus and Ebscohost) using the following guidelines: 1) "Momordica charantia" OR "Bitter melon", 2) "Momordica. Foetida" or "Bitter cucumber", and 3) "Momordica. Balsamina" OR "African pumpkin". The common search for peer reviewed article used included the biochemical, nutritional, and medicinal values or composition of Momordica spp. The same search was also conducted using the common names of the species. The search was filtered based on the year of publications (Year $=1990-2020)$ to obtain most recent literature however, it did not exclude the old publications (Year<1990) which form the basic knowledge of the associated literature. Since, the study was limited to qualitative synthesis, the PRISMA 2009 Flow Diagram (Moher et al., 2009) was to modified to exclude the meta-analysis aspects (Figure 1).

\section{BIOCHEMICAL COMPOSITION AND ACTIVITY OF THE THREE SELECTED MOMORDICA SPECIES}

\section{Momordica charantia L.}

$M$. charantia is a good source of primary metabolites such as carbohydrates, fibers, proteins, minerals, and vitamins. The most important chemical constituents from $M$. charantia include heteropolysaccharides (e.g., arabinose, galactose, glucose, mannose and rhamnose); proteins and peptides (e.g., momordins, momorcharins, etc); terpenoids and saponins (e.g., cucurbitanes and cucurbitacines); flavonoids and phenolic compounds (Chen et al., 2003; Harinantenaina et al., 2006; Schrot et al., 2015; Dandawate et al., 2016; Lee et al., 2021). M. charantia also contains triterpenes, proteins, steroids, alkaloids, lipids (lauric, myriaatic, palmitic, stearic, linoleic, and eleostearic acids), phenolic compounds and minerals $(\mathrm{Cu}$, 
Muronga et al.

Phytochemical Constituents of Genus Momordica

TABLE 1 | Compounds extracted from Momordica charantia L. and their health benefits.

\begin{tabular}{lcc}
\hline Compound & Structure & Health benefits \\
Momordicoside $\mathrm{F}_{2}$ & References & Anti-inflammatory and \\
anti-cancer & Ju et al. (2004), Cao et al. \\
(2018) & O' & and
\end{tabular}

Goyaglycoside B

Karaviloside III

Charantoside VI

Charantagenin $\mathrm{E}$

Charantoside II
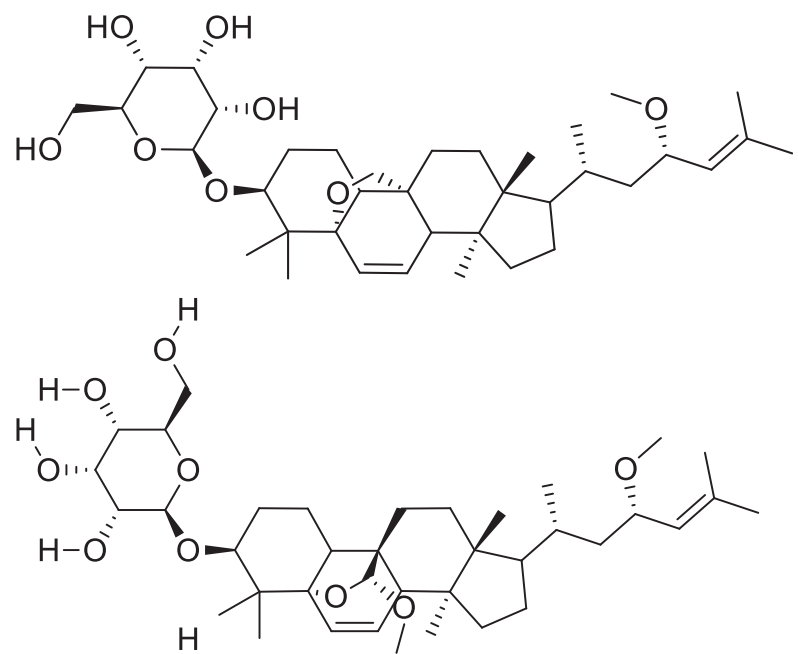

Anti-aging

Cao et al. (2018)

Anti-aging

Cao et al. (2018)

Anti-aging

Cao et al. (2018)

Anti-aging

Cao et al. (2018)
Raina et al. (2016), Cao et al. (2018)

Charantoside II

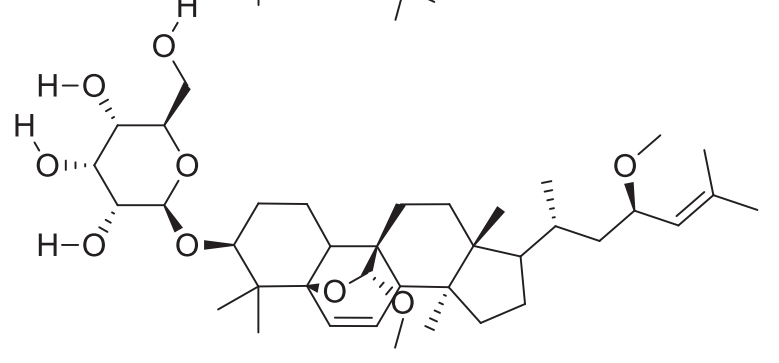

(Continued on following page)

Frontiers in Pharmacology | www.frontiersin.org

4

May 2021 | Volume 12 | Article 625546 
TABLE 1 | (Continued) Compounds extracted from Momordica charantia L. and their health benefits.

\section{Compound}

Momordicoside G

Goyaglycoside D

Stigmasterol glucoside

$\beta$-sitosterol glucoside<smiles>C[C@@H]1O[C@H](COP)[C@@H](O)[C@H](O)[C@@H]1O</smiles><smiles>OCC1OC(O)[C@H](O)C(O)[C@@H]1O</smiles>

Structure

Health benefits

Anti-aging

References

Cao et al. (2018)
Anti-cancer

Anti-angiogenic and anticancer
Wang et al. (2012), Cao et al. (2018)
Cholesterol reduction and immune system modulation
Kaur et al. (2011), Desai and Tatke, (2015)
Desai and Tatke, (2015), Kangsamaksin et al. (2017)
(19R)-7 $\beta, 19-e p o x y-19-$ methoxycucurbita-5,24-dien3ß,23-diol
Anti-aging

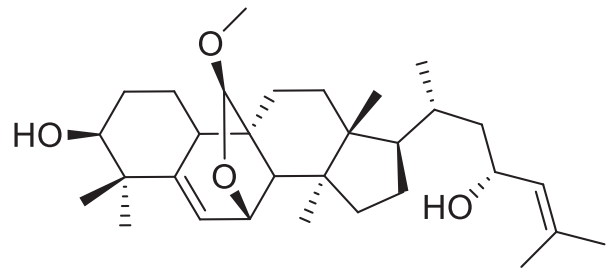

Jiang et al. (2016), Cao et al. (2018)

Kuguacin J<smiles>C=C(C)/C=C/C[C@H](C)C1CC[C@]2(C)C3[C@H](O)C=C4C(CC[C@H](O)C4(C)C)[C@@]34CC[C@]1(C)C24</smiles>

Limtrakul et al. (2013), Chen et al. (2015) 
TABLE 1 | (Continued) Compounds extracted from Momordica charantia L. and their health benefits.

Compound
Cucurbitane triterpenoid

Cucurbitane triterpenoid

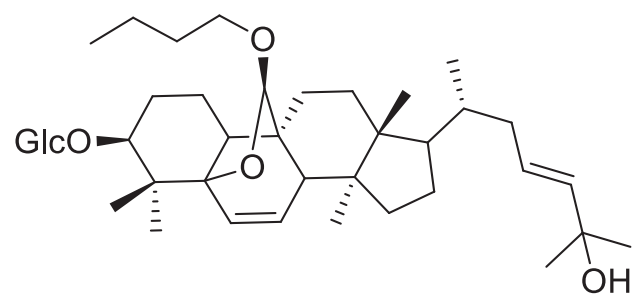

Steroidal glycoside

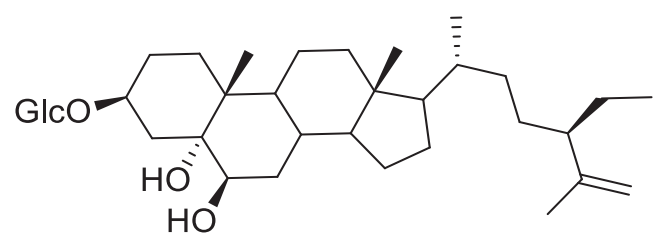

Anti-cancer

Reduce blood sugar level

Liu et al. (2009), Tan et al. (2015b), Lee et al. (2021)
Fe, Mg, Zn, and Ca) (Yuwai et al., 1991; Kumar and Bhowmik, 2010; Joseph and Jini, 2013; Tokhtar and Doan, 2014; Tan E. S. et al., 2015; Yoshime et al., 2016). The leaves and flowers of $M$. charantia contains triterpenoids (momordicine and charantin), carotenoids (antheraxanthin, lutein, violaxanthin, $\alpha$-carotene, and $\beta$-carotene), and phenylpropanoids (caffeic acid, chlorogenic acid, epicatechin, gallic acid, p-coumaric acid, rutin, and trans-cinnamic acid) (Sathasivam et al., 2021). The water content of the fruits of $M$. charantia is about $93.2 \%$, while protein and lipids content ranges between 18.02 and $0.76 \%$ (Saad et al., 2017). The fruit pulp of $M$. charantia consists of soluble pectin and galactouronic acid. Moreover, the fruits consist of glycosides, saponins, alkaloids, reducing sugars, resins, phenolic constituents, fixed oil and free acids (Bakare et al., 2010). Green fruits of $M$. charantia contain Vitamin A, Vitamin C, and Vitamin $p$, thiamine, riboflavin, niacin, and minerals (Gupta et al., 2011). The essential oil, obtained from water stressed seeds also contains sesquiterpenes, phenylpropanoids and monoterpenes, however seed oil contain tocopherols and polyphenols (Nyam et al., 2009). The phenolic compounds that are found on all parts of the crop protect the plant from oxidative damage (Yoshime et al., 2016; Wardani et al., 2021).

Among the bioactive compounds that have been isolated from the fruits of $M$. charantia and elucidated by nuclear magnetic resonance (NMR) and mass spectrometry (MS) spectroscopic techniques include Monordicophenoide A (4-hydroxyl-benzoic acid $\quad 4-O-\beta$-D-apiofuranosyl $\quad(1 \rightarrow 2)-O-\beta$-D-glucopyranoside; dihydrophaseic acid 3-O- $\beta$-D-glucopyranoside; momordicolide (10E)-3-hydroxyl-dodeca-10-en-9-olide; 6,9-dihydroxymegastigman-4,7-dien-3-one (blumenol); adenosine; guanosine; uracil; and cytosine (Li et al., 2009). Those isolated from the leaves of $M$. charantia include Momordicin I, Momordicin IV, aglycone of Momordicoside, aglycone of Momordicoside L; and Karavilagenin D were identified (Li et al., 2015). The essential oil such as trans-nerolidol, apiole, cis-dihydrocarveol, and germacrene $\mathrm{D}$ were isolated from the seeds of $M$. charantia and identified by gas chromatography mass spectrometry (GC/ MS) (Braca et al., 2008).

Main phenolic acids found in $M$. charantia are gallic acid, chlorogenic acid, catechin, caffeic acid, p-coumaric acid, and ferulic acid (Lee et al., 2017). Compounds such as capxanthin, lutein, zeaxanthin, $\beta$-cryptoxanthin, lycopene, $\alpha$-carotene, and $\beta$-carotene have also detected from the fruit of $M$. charantia (Lee et al., 2017). The variation in phenolic acids and carotenoids contents at different maturity stages create a strong relationship with the anti-oxidant activities of $M$. charantia fruit. The crop consists of non-essential amino acids such as arginine, alanine, aspartic acid, glycine, glutamic acid, proline, histidine and serine. Such non-essential amino acids are inherently higher in concentration, as compared to essential amino acids such as leucine, cysteine, phenylalanine, isoleucine, methionine, lysine, threonine, tyrosine and valine. From the leaves of $M$. charantia leucine and aromatic (tyrosine and phenylalanine) were the predominant amino acids, while aspartic acid and glutamic 
acid are major non-essential amino acids of this plant (Khanna, 2004).

Other reported phytochemical compounds from $M$. charantia plant were obtained after being extracted and their chemical structures identified using NMR. These include $\beta$-sitosterol; (23E)-5 $\beta, 19$-epoxycucurbita-6,23-diene-3 $\beta, 25$-diol; daucosterol; uracil; and allantoin using spectroscopic analysis including MS and $1 \mathrm{H}$ - and C-NMR (Kim et al., 2018). The structures of momordicosides $\mathrm{K}$ were identified as $7-O-\beta-\mathrm{D}$ glucopyranosides of $3 \beta, 7 \beta$-dihydroxy-25-methoxy-cucurbita-5; 23-dien-19-al; and momordicosides $\mathrm{L}$ as $3 \beta, 7 \beta, 25$-trihydroxycucurbita-5,23-dien-19-al (Okabe et al., 1982).

\section{Momordica foetida Schumach}

$M$. foetida have been reported to contain secondary metabolites such as sitosterylglucoside, 5,25-stigmastadien-3 $\beta$-ylglucoside, and $1 \beta$ hydroxyfriedel-6-en-3-one, and a lot of cucurbitane-type triterpenoid derivatives (Molehin and Adefegha, 2014). Phenolic glycosides of $M$. foetida include eriodictyol-, kaempferol- 5,7,4 ${ }^{\prime}$ trihydroxyflavanone, and 5,7-dihydroxychromone-7-O- $\beta$-Dglucopyranoside (Froelich et al., 2007).

The crop species of $M$. foetida contain 25-trihydroxycucurbita5,23-dien-19-al and 3 $\beta, 7 \beta$-dihydroxy-25 methoxycucurbita-5,23dien-19-al; $3 \beta, 7 \beta, 23 \xi$-trihydroxycucurbita-5,24-dien-19-al, $3 \beta$, $7 \beta$. Others include $5 \beta, 19$-epoxy-25-methoxycucurbita-6,23diene-3 $\beta, 19$-diol, $5 \beta, 19$-epoxycucurbita-6,23-diene- $3 \beta, 19,25$ triol,5 $\beta, 19$-epoxy-19 methoxycucurbita-6, 23-diene-3 $\beta, 25$ diol,5 $\beta, 19$-epoxy-19,25-dimethoxycucurbita-6,23-dien-3 $\beta$-ol and 5 $\beta, 19$-epoxy-25-methoxy-cucurbita-6,23-dien-3 $\beta$-ol (Mulholland et al., 1997). Secondary metabolites detected in $M$. foetida are steroids, alkaloids, cardiac glycosides, phenolics, tannins, flavonoids and saponin (Ndam et al., 2014).

The chemical structures of the isolated compounds include $3 \beta, 7 \beta$-dihydroxyl-cucurbita-5,23,25-trien-19-al followed by Kaempferol-3-O- $\beta$-D-glucopyranoside have anti-microbial activity (Odeleye et al., 2009). The fruits and leaves of $M$. foetida crop contain Momordicines and Foetidin (identical to Charantin). Phytochemical analysis of $M$. foetida revealed phenolic glycosides such as eriodictyol-, 5,7,4'-trihydroxyfl avanone-, kaempferol- and 5,7-dihydroxychromone-7-O- $\beta$-Dglucopyranoside (Froelich et al., 2007). Other phytochemical analysis of $M$. foetida extract led to the presence of alkaloids, saponins and cardenolides (Odusote and Awaraka, 2004).

\section{Momordica balsamina L.}

The leaves, fruits, seeds, and bark of the M. balsamina contains secondary metabolites such as alkaloids, flavonoids, glycosides, steroids, terpenes, cardiac glycoside, saponins, tannins and lectins (Talukdar and Hossain, 2014). The matured seeds are the main source of plant lectins (Abegunde et al., 2018). The primary metabolites include crude lipid (2.66\%), common sugars, proteins (11.29\%), crude fiber (29\%), energy, amino acid, carbohydrates (39\%) and chlorophyll (Hassan and Umar, 2006; Thakur et al., 2009; Orhan et al., 2010; Ibrahim et al., 2014; Birla, 2016; Abegunde et al., 2018).

The leaves are an important source of nutrients, in addition they contain 17 amino acids and an adequate mineral composition (Hassan and Umar, 2006; Talukdar and Hossain, 2014; Wardhani et al., 2015; Wang et al., 2016; Nitu and Patidar, 2017). M. balsamina is rich potassium, calcium, magnesium, sodium, phosphorus, manganese, zinc, and iron which contribute to prevent micronutrient deficiencies in human.

\section{NUTRITIONAL VALUE OF THE THREE SELECTED MOMORDICA SPECIES}

\section{Momordica charantia L.}

$M$. charantia fruit is commonly eaten unripe as a vegetable and is also used as herbal plant that is useful in metabolic and physiological processes of the human body. It is advisable to add peeled fruits to minimize bitter taste before preparation which involves soaking the fruits and shoots and then boiled, fried or pickled (Kumar and Bhowmik, 2010). M. charantia fruits are known to have high levels of nutritional value (protein, vitamins, thiamine, riboflavin, calcium and iron) compared to other cucurbits it has higher in folate and Vitamin C and the vine tips as an excellent source of Vitamin A. M. charantia leaves can be harvested, cooked and consumed alone or mixed with other indigenous vegetables to limit the bitterness (Hassan and Umar, 2006). The leaves and fruits of M. charantia have been used to make teas and beer or season soups in the Western world (Kumar and Bhowmik, 2010).

$M$. charantia contains iron, $\beta$-carotene, calcium potassium, vitamins, phosphorus and good dietary fiber (Daniel et al., 2014). About $93.2 \%$ of the fruit of $M$. charantia is composed of water, while protein and lipids account for 18.02 and $0.76 \%$, respectively, ( $\mathrm{Li}$ et al., 2009). Leaves powder from $M$. charantia contained $38 \%$ water, $38.2 \%$ dietary fiber, $67 \%$ minerals, $45 \%$ crude protein and $27 \%$ crude fat (Anilakumar et al., 2015). Protein lectin that is found on the seed of $M$. charantia is responsible for the inhibition of protein synthesis in the intestinal walls of an animal without producing any gastrointestinal symptoms in humans.

$M$. charantia seeds may induce fauvism in humans with glucose- 6 phosphate dehydrogenase deficiency (Harinantenaina et al., 2006; Krawinkel and Keding, 2006; Ludidi et al., 2019). Some studies reported that $M$. charantia leaf powder inhibited adipocyte hypertrophy in diet-induced obese rats due to the process of decreasing lipogenic genes including fatty acid synthase, acetyl CoA carboxylase, lipoprotein lipase and adipocyte fatty acid and protein in epididymis fat (Tansey et al., 2004; Nerurkar et al., 2010; Anilakumar et al., 2015).

$M$. charantia reduced the accumulation of visceral fat that was fed to rats with high fat diet it and thus help in reducing insulin sensitizing and glucose due to its anti-adiposity effect (Chen et al., 2003; Huang et al., 2008; Dellavalle et al., 2011). Circulating levels of catecholamine and non-esterified fatty acids, lipid oxidation in the liver and muscle are reported to be as a result of $M$. charantia supplemented rat (Cohen et al., 1998; Waako et al., 2005; Harinantenaina et al., 2006; Bulbul, 2016; Devyani et al., 2016).

\section{Momordica foetida Schumach}

The crop is commercially grown for their nutritional value and they are also used for medicinal purposes (Waako et al., 2005). 
TABLE 2 | Compounds extracted from Momordica foetida Schumach. and their health benefits.

\section{Compound}

Quercetin malonlglycoside diglycoside

Kaempferol Acetylglycoside

Quercetin acetylglycoside

\section{Structure}<smiles>O=C(O)CC(=O)OCC1OC(Oc2c(-c3ccc(O)c(O)c3)oc3cc(O)cc(O)c3c2=O)C(O)C(O)C1O</smiles>

Lowers blood pressure and inflammation

Health benefits

Khoza et al. (2016), Dabeek and Marra, (2019)

Anti-tumor, anti-oxidant and antiinflammatory

Khoza et al. (2016), Abegunde et al. (2018)
Khoza et al. (2016), Abegunde et al.

Anti-tumor, anti-oxidant and antiinflammatory

\section{(2018)}

Lowers blood pressure and inflammation
Khoza et al. (2016), Dabeek and Marra, (2019)

(Continued on following page) 
TABLE 2 | (Continued) Compounds extracted from Momordica foetida Schumach. and their health benefits.

\section{Compound}

Isorhamnetin acetyl-

glycoside

Isorhamnetin glycoside<smiles>COc1ccc(-c2oc3cc(O)cc(O)c3c(=O)c2OC2OC(COC(C)=O)C(O)C(O)C2O)cc1O</smiles><smiles>COc1ccc(-c2oc3cc(O)cc(O)c3c(=O)c2OC2OC(CO)C(O)C(O)C2O)cc1O</smiles>

Quercetin glycoside<smiles>O=c1c(OC2OC(CO)C(O)C(O)C2O)c(-c2ccc(O)c(O)c2)oc2cc(O)cc(O)c12</smiles>

Kaempferol glycoside<smiles>O=c1c(OC2OC(CO)C(O)C(O)C2O)c(-c2ccc(O)cc2)oc2cc(O)cc(O)c12</smiles>

Health benefits

References

Anti-oxidant, anti-viral, anticancer, antimicrobial, and anti-inflammatory

Khoza et al. (2016), Kandakumar and Manju, (2017)
Anti-oxidant, anti-viral, anticancer, antimicrobial, and anti-inflammatory
Khoza et al. (2016), Kandakumar and Manju, (2017)
Lowers blood pressure and inflammation
Khoza et al., (2016), Dabeek and Marra, (2019)
Anti-tumor, anti-oxidant and antiinflammatory
Khoza et al. (2016), Abegunde et al. (2018)

(Continued on following page) 
TABLE 2 | (Continued) Compounds extracted from Momordica foetida Schumach. and their health benefits.

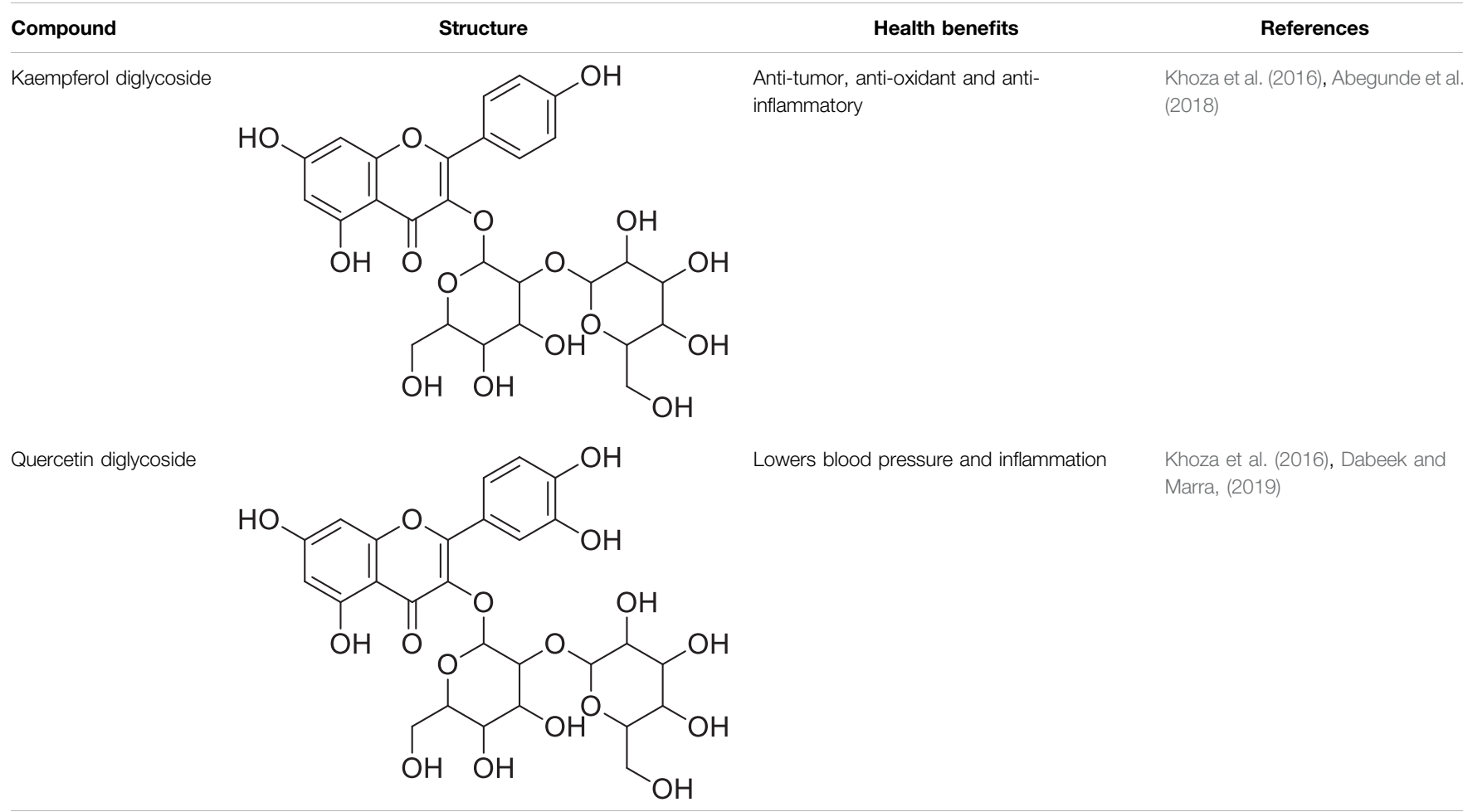

Phytochemical composition

$\begin{array}{lc}\text { Biological activities } & \text { Medicinal value in } \\ \text { Anti-microbial } & \text { Gastrointestical diseases } \\ \text { Anti-parasitic } & \text { Cancer } \\ \text { Anti-ulcer } & \text { Aging } \\ \text { Anti-cancer } & \text { Neurological diseases } \\ \text { Anti-oxidant } & \text { Diabetes } \\ \text { Hypoglycemic } & \text { Cardiovascular disease } \\ \mathrm{Hypocholesterolemic}^{\mathrm{Na}^{+} / \mathrm{K}^{+} \text {ratio }} & \text { Hypertension } \\ \end{array}$

FIGURE 2 | Summarized biological activies and medicinal value of Momordica charantia L. Momordica foetida Schumach. and Momordica balsamina L. (African pumpkin).

The leaves of $M$. foetida are harvested from the wild and consumed when they are prepared as a vegetable in Gabon, Sudan, Uganda, Tanzania, South Africa and Malawi and some other African countries. The leaves of $M$. foetida are harvested, boiled and consumed with beans or peas together with a staple food. It is utilized in small amounts as a famine food and in emergency situations.
Traditional people prefer to consume $M$. foetida pulp of ripe fruits even if it has bitter taste (Mada et al., 2013; Mostafa et al., 2018; Ludidi et al., 2019). M. foetida leaves can be mixed with other vegetables to make a stew. It is also sauced with shrimp, meat, pork, and chicken and served with gravy. The leaves are mixed with ground peanuts and honey as a sauce in meat (Thakur et al., 2009; Dellavalle et al., 2011; Oronje et al., 2012; Sen and 
TABLE 3 | Compounds extracted from Momordica balsamina $L$. and their health benefits.

\section{Compound}

Cucurbitane glycoside

Kuguacin J

\section{Karavilagenin C}

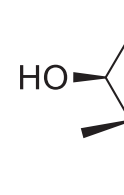

Structure

Health benefits

Anti-diabetic<smiles>CCC[C@H](C)C[C@H](O)C=C(C)C</smiles>

O\}<smiles>C=C(C)/C=C/C[C@@H](C)C1CC[C@]2(C)C3[C@H](O)C=C4C(CC[C@@H](O)C4(C)C)[C@@]3(C=O)CC[C@]12C</smiles>

$\mathrm{H}^{\prime}$<smiles>CO[C@H]1C=C2C(CC[C@@H](O)C2(C)C)[C@@]2(C)CC[C@]3(C)C([C@@H](C)CC(O)C=C(C)C)CC[C@@]3(C)C12</smiles>

Balsaminagenin A<smiles>C[C@H](C/C=C/C(C)(C)O)C1CC[C@]2(C)C3[C@H](O)C=C4C(CC[C@@H](O)[C@@]4(C)CO)[C@@]3(C)CC[C@]12C</smiles>

Anti-cancer

\section{References}

Spengler et al. (2009), Farooc et al. (2019)

Spengler et al. (2009), Santos et al. (2012)

Ramalhete et al. (2009), Ma et al. (2012)

Ramalhete et al. (2009), Ma et al. (2012)

Ramalhete et al. (2009), Ma et al. (2012)
Schistosomicidal activity against Schistosoma mansoni adult worms
Ramalhete et al. (2011), Ramalhete et al. (2016)

(Continued on following page) 
TABLE 3 | (Continued) Compounds extracted from Momordica balsamina L. and their health benefits.

Compound

Momordin II

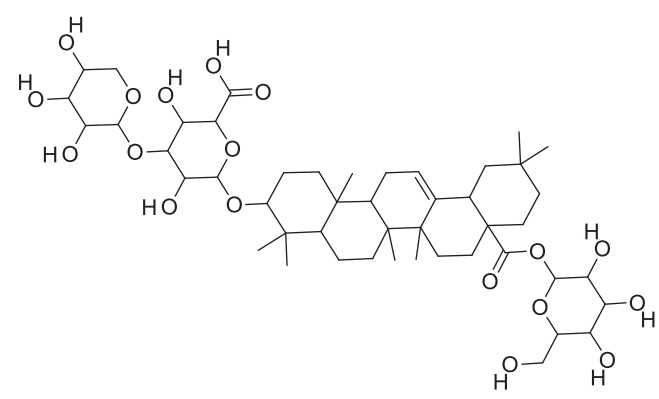

Balsaminapentaol<smiles>C=C(C)[C@H](O)[C@@H](O)C[C@@H](C)C1CC[C@]2(C)C3[C@H](O)C=C4C(CC[C@@H](O)[C@@]4(C)CO)[C@@]3(C)CC[C@]12C</smiles>

Cucurbalsaminol

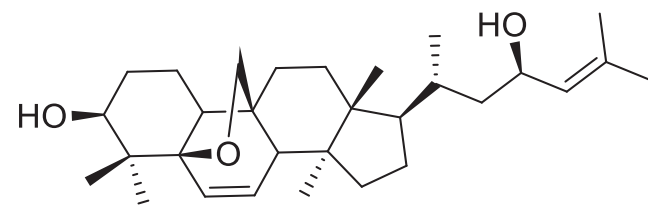

Anti-viral

Thakur et al. (2009)
Ramalhete et al. (2009), Ma et al. (2012)
Ma et al. (2012), Shah et al. (2014)
Batra, 2012; Fongod et al., 2014; Talukdar and Hossain, 2014; Bulbul, 2016; Poyraz and Derdovski, 2016; Nitu and Patidar, 2017; Mostafa et al., 2018).

M. foetida leaves are used as fodder and protein supplement in some countries and are suitable for increasing rabbits weight (Jabeen and Khanum, 2017). However, reports from Kenya state that cattle avoid M. foetida because of its unusual smell and bitter taste.

Nutritional composition of $M$. foetida leaf is energy, protein, fiber, calcium, iron, magnesium, zinc, $\beta$-carotene, foliate and ascorbic acid (Oloyede and Aluko, 2012; Puškárová et al., 2017; Abegunde et al., 2018). The leaves of M. foetida contain considerable amount of anti-oxidants and are capable of inhibiting lipid peroxidation (Oloyede and Aluko, 2012; Acquaviva et al., 2013; Anilakumar et al., 2015; Dzotam et al., 2016; Puškárová et al., 2017; Anjamma and Bhavani, 2018). Triterpenes are found in both $M$ charantia and $M$. foetida, particularly in the fruits and seeds, and are potentially cytotoxic.

\section{Momordica balsamina L.}

M. balsamina is important in producing nutrients supplements due its high protein and fat values with low fiber content (Bakare et al., 2010; Costa et al., 2010; Roškar and Lušin, 2012; Ghosh, 2014; Madala et al., 2014; Talukdar and Hossain, 2014; Abegunde et al., 2018). The leaves of M. balsamina are an important source of nutrients, including 17 amino acids (Cohen et al., 1998; Hassan and Umar, 2006; Costa et al., 2010; Semenya and Potgieter, 2015). M. balsamina leaves are mixed with peanuts and honey and used as a meat sauce (Dellavalle et al., 2011; Oronje et al., 2012; Sen and 
Batra, 2012; Fongod et al., 2014; Bulbul, 2016; Poyraz and Derdovski, 2016; Mostafa et al., 2018).

The fruit of M. balsamina contains the red, soft flesh that surround the edible seed (Tan C. et al., 2015; Birla, 2016; Devyani et al., 2016; Souda et al., 2018). The tender fruits and shoots of $M$. balsamina are usually boiled with meat and both can be decided to be added to the soup. Young fruits of M. balsamina are cooked and eaten, after peeling it is advisable to put on the salt water to minimize the bitterness before cooking, additionally the South Africans and Nigerians appreciate the fruit for its better taste (Acquaviva et al., 2013; Ghosh, 2014; Souda et al., 2018). The fruits of M. balsamina are frequent ingredients used in Indo Pakistan pickles and they are often used in curries and meat dishes.

Tender shoots of M. balsamina are usually utilized with Okra soup by the Kanuris of Borno State where the plant is locally known as the vegetable (Jabeen and Khanum, 2017). M. balsamina is preferred as an ingredient in aphrodisiac preparations however in Senegal they prefer to use the fruits as purgative agents, poultice and vermifuge (Leung et al., 2009; Souda et al., 2018).

\section{MEDICINAL VALUE OF THE THREE MOMORDICA SPECIES}

\section{Momordica charantia L.}

$M$. charantia has medicinal value and is also used as a vegetable. The compounds present in $M$. charantia exert anti-diabetic, anticancerous and anti-tumorous, anti-microbial, anti-viral, antihelmintic, antimalarial, anti-ulcerative and immunomodulatory activities (Gupta et al., 2011; Kulkarni et al., 2021; Lur et al., 2021; Malik et al., 2021). Some of the structures of compounds isolated from $M$. charantia are listed in Table $\mathbf{1}$.

Various medicinal properties have been claimed to be associated with $M$. charantia and they include anti-diabetic, abortifacient, anthelmintic, contraceptive, anti-malarial and laxative are used for various treatment such as dysmenorrhea, eczema, emmenagogue, galactagogue, gout, jaundice, kidney (stone), leprosy, leucorrhea, pneumonia, psoriasis, rheumatism, scabies, and piles (Grover and Yadav, 2004; Kumar and Bhowmik, 2010; Chen et al., 2011; Acquaviva et al., 2013; Ghosh, 2014; Bulbul, 2016; Perera et al., 2021).

The fruit juice and a leaf tea extracted from $M$. charantia can be used for the treatment of diabetes, malaria, colic, sores and wounds, infections, worms and parasites, as an emmenagogue, and for measles, hepatitis, and fevers (Kumar and Bhowmik, 2010). The anti-oxidants and chemo-protective are mostly available on $M$. charantia fruit extracts drug that helps with reducing risk of cancer (Dzotam et al., 2016; Khalid et al., 2021). The leaves of $M$. charantia are used for treatment of wounds as well against worms and parasites. $M$. charantia has been used as a traditional medicine in China, India, Africa, and the southeastern United States (Grover and Yadav, 2004). In the 1980s, the seeds of $M$. charantia were investigated in China as a potential contraceptive (Kumar and Bhowmik, 2010).
Natural products from $M$. charantia have been reported to significantly decrease prostaglandin E2, interleukin and tumor necrosis factor and increases transforming growth factor and IL10 secretion in RAW 264.7 macrophages, Caco- 2 cells and THP-1 cells (Tan et al., 2008). The $M$. charantia fruit effectively enhanced $\mathrm{T}$ helper 2 hormonal responses and $\mathrm{T}$ helper 1 cellular immunity. A mixture of steroidal saponins contribute to the hypoglycemic and anti-hyperglycemic activity of $M$. charantia (Nitu and Patidar, 2017). Gentisic acid found as an active metabolite of salicylic acid and relation of the antiinflammatory property of salicylic acid by inhibiting cyclooxygenase-2 (COX-2) mRNA expression and activity as well as prostaglandin E2 (Lii et al., 2009; Semenya and Potgieter, 2015; Wardhani et al., 2015; Madala et al., 2016; Wang et al., 2016).

$M$. charantia have been reported to exhibit anti-diabetic, anthelmintic, abortifacient, anti-bacterial, anti-viral, hypoglycemic agents and chemo-preventive functions (Grover and Yadav, 2004; Costa et al., 2010; Ghosh, 2014; Bulbul, 2016; Dzotam et al., 2016; Ludidi et al., 2019; Kulkarni ei al. 2021). The fruits and leaves of $M$. charantia display various biological activities including anti-diabetic, anti-rheumatic, and antiulcer, anti-inflammatory and anti-tumor (Dzotam et al., 2016). M. charantia contains various chemicals that have a hypoglycemic activity which reduces the amount of sugar in the blood, furthermore it stimulates appetite and helps in the entire digestion process. $M$. charantia is used for the treatment of digestive problems (Ludidi et al., 2019).

The leaves of $M$. charantia are used to treat diabetes, intestinal gas, promote menstruation, and as anti-viral agent against measles and hepatitis viruses (Tansey et al., 2004; Leung et al., 2009; Costa et al., 2010; Nerurkar et al., 2010; Nitu and Patidar, 2017; Perera et al., 2021; Liu et al., 2021). M. charantia is used by most of the culture for minimizing blood glucose and treating diabetes and as the other admired herbal resource (Leung et al., 2009; Birla, 2016). Hypoglycemic potential of M. charantia has been demonstrated in patients with type 2 diabetes. Emerging evidence also suggest that hypolipidemic action of $M$. charantia lowers serum cholesterol, hepatic total cholesterol and triglyceride and elevated cholesterol (Chen et al., 2003; Tan et al., 2008). The crop juice is believed significantly to reduce lipid accumulation and increase lipolysis in primary human adipocytes (Tan E. S. et al., 2015; Ingle et al., 2017). Animal studies indicate that $M$. charantia juice reduces body weight by inducing a reduced adipose hypertrophy, inhibition of lipogenic genes and enlarged plasma catecholamines (Nerurkar et al., 2010).

The ripe fruit of $M$. charantia fruits had been used as a remedy for tumors, asthma, skin infections and hypertension (Semenya and Potgieter, 2015). The seeds are surrounded by sweet red fleshy pulp that is edible tasting like watermelon (Poyraz and Derdovski, 2016). In some parts of West Africa, the leaves of $M$. charantia are cooked as part of green vegetable soup for post-natal mothers to prevent loss of blood during labor and purify breast milk. However, M. charantia can be recommended to use for livestock feeding as supplement for protein (Kuete et al., 2010). 


\section{Momordica foetida Schumach}

Traditional medicinal uses are numerous, and many are shared with other Momordica spp. In East and Central Africa, M. foetida extracts are used to treat hypertension, peptic ulcers, and diabetes. Foetidin isolated from M. foetida is capable of reducing bloodglucose level in fasting albino rats (Marquis et al., 1977). Likewise, M. foetida is used for treatment of digestive problems due to its hypoglycemic activity that reduces the amount of sugar in the blood and also stimulate appetite and helps in the entire digestion process (Leung et al., 2009; Kumar and Bhowmik, 2010; Chen et al., 2011; Daniel et al., 2014; Birla, 2016).

Additionally, $M$. foeida has slight anti-spasmodic and anticholinergic effects (Hassan and Umar, 2006; Acquaviva et al., 2013; Ingle et al., 2017; Puškárová et al., 2017). Some of the structures of compounds extracted from M. foetida are listed in Table 2.

Aqueous extract of $M$. foetida has anti-oxidant activity due to high content in phenolic and flavonoid compounds (Acquaviva et al., 2013). Oxidative stress is closely related with Alzheimer and Parkinson diseases, diabetes, rheumatoid arthritis, and several diseases. The use of anti-oxidants in pharmacology has been instrumental in treatments of stroke and neurodegenerative diseases (Jabeen and Khanum, 2017).

The juice of $M$. foetida, dried and crushed leaves are used to relieve cough, intestinal disorders, headache, earache, toothache and as an cure for snake bites (Jabeen and Khanum, 2017). Leaves can be dried or boiled and used to treat skin problems, spitting cobra poison and malaria. The roots of $M$. foetida may be stated to be poisonous, and the crushed seeds are used in East Africa to cure of constipation. $M$. foetida helps to reduce weight in obese people (Nerurkar et al., 2010; Talukdar and Hossain, 2014).

The fruit pulp of $M$. foetida is said to be poisonous to common pests such as weevils, moths and ants, making it to be utilized as potential insect repellent in Tanzania. Momordocin isolated from M. foetida has insecticidal ability (Olaniyi and Marquis, 1975; Pinar et al., 1983; Pirillo et al., 1995). In Uganda the M. foetida whole plant is use on their cattle as an ox pecker repellent. In Gabon, $M$. foetida soaked and dried leaves are used to stuff cushions for commercial purpose. $M$. foetida is preferred to be grazed by cattle (Kuete et al., 2010; Mada et al., 2013) and is said to be good supplement of protein (Talukdar and Hossain, 2014). The fruits have the essential oils they have been used as insecticides, food additives and aromatherapy (Dandawate et al., 2016).

\section{Momordica balsamina L.}

M. balsamina is regarded as the most important medicinal plants popularly used as a source of life saving drugs that is most important to the world's population (Hassan and Umar, 2006; Thakur et al., 2009; Kumar and Bhowmik, 2010; Tan C. et al., 2015; Souda et al., 2018). The crop can be consumed as vegetable in order to supply protein and potassium supplement for diets in poor rural communities, however its high potassium content is known for the executive of hypertension and other cardiovascular conditions (Rahmatullah et al., 2012; Semenya and Potgieter, 2015; Jabeen and Khanum, 2017; Souda et al., 2018). Some of the structures of compounds extracted from M. balsamina are listed in Table 3.
In some parts of Africa and Europe, soaked leaves of $M$. balsamina are used to treat wounds. Furthermore the fruits and leaves are used for treatment of wounds in Nigeria and Syria as hemostatic anti-septic (Mada et al., 2013; Semenya and Potgieter, 2015; Madala et al., 2016). The fruit of M. balsamina is used as liniment because of its strong smell and mixed with olive oil and almond oil to treat chapped hands, band and hemorrhoids (Mada et al., 2013). In West Africa M. balsamina fruit pulp is mixed with oil as an anti-phlogistic dressing. Mashed fruit of M. balsamina is utilized as poultice and bitter tonic (Semenya and Potgieter, 2015). M. balsamina plant is used as a medicine for treatment of fevers and yaws. However, Tsonga and Zulus have used leaves as tea for blood-liver deficiencies, stomach and intestinal ailments (Kumar and Bhowmik, 2010).

The Portuguese recommended $M$. balsamina leaves for blood, stomach, and liver deficiencies, furthermore they use leaves for herbal medicine and culinary herb (Thakur et al., 2009; Madala et al., 2014). M. balsamina leaves are used for diabetes, digestion disorder, fevers, ulcers, and mild form of malaria. Additionally, in West Africa M. balsamina is used as medicine in human and animals particular for fever, yaws and purgative (Oloyede and Aluko, 2012; Ingle et al., 2017; Jabeen and Khanum, 2017; Mostafa et al., 2018). M. balsamina roots are used as ingredient in an aphrodisiac preparation and in treatment of urethral discharge on both human and animals. It is advisable to use the whole M. balsamina parts of the plant for used in treating skin disease such as scabies (Waako et al., 2005; Ozusaglam and Karakoca, 2013; Pauliuc and Botau, 2013; Wikaningtyas and Sukandar, 2016). In South Africa, mostly the Pedi people use M. balsamina leaves and tendrils as potherb and anti-emetic, while the Venda people used the leaves infusions as anti-emetic and Congo as colic. $M$. balsamina leaves and fruit are widely used in Okavango delta for medicinal and spiritual purpose and also as skin aliments in China (Molehin and Adefegha, 2014). In some countries seed can be used as poison in arrow for hunting. The whole plant extract has insecticidal properties (Trakoon-osot et al., 2013; Wardhani et al., 2015; Wang et al., 2016).

The aqueous leaf extract of M. balsamina has also been used to minimize and relieve period pain in young girls and postnatal women used it to stimulate milk production (Tan et al., 2008). In Hausa land of Nigeria and Republic of Niger, the leaves are cooked as part of green vegetables soup for post-natal women, where it is believed to help the mother to restore her lost blood during labor and to cleanse her breast milk (Molehin and Adefegha, 2014).

Anti-oxidants are recognized as ingredient and supplement of good human health because they maintain health and prevent diseases such as cancer, coronary heart disease and even altitude sickness in human and animals (Tan et al., 2008; Ingle et al., 2017; Puškárová et al., 2017). M. balsamina is used for treatment of diabetes, malaria, colic, sores and wounds, infections, worms and parasites, as an emmenagogue, measles, and hepatitis, fevers, diarrheal, cancer, ulcer, HIV, bacterial infection, and constipation (Semenya and Potgieter, 2015; Abegunde et al., 2018; Aryanti and Lamdayani, 2021). In addition, M. balsamina is believed to treat mental illness (Anjamma and Bhavani, 2018). The anti-HIV properties are 
found at the fruit pulp of M. balsamina (Abidemi, 2013). The leaves and fruit extracts of $M$. balsamina contain antiplasmodial activity against malaria (Balouiri et al., 2016). The crude extract of protein on African pumpkin seeds contains a hemagglutinating activity attributed by the presence of sugar D-galactose and lactose (Bulbul, 2016). Moreover, several previous studies did test the hemagglutinating activity on human and animals of the different blood type and proved that the hemagglutinating was greater toward O blood type compared to other blood cell type (Scorzoni et al., 2007; Souda et al., 2018).

The fruit juice of $M$. balsamina exerted hypoglycemic activity, stimulates appetite and helps in the entire digestion process (Kumar and Bhowmik, 2010; Chen et al., 2011). Hypoglycemic potential of $M$. balsamina has been established in normal and diabetic rats and in patients with type 2 diabetes (Waako et al., 2005; Scorzoni et al., 2007; Leung et al., 2009; Kumar and Bhowmik, 2010; Rahmatullah et al., 2012; Joseph and Jini, 2013; Trakoon-osot et al., 2013; Ludidi et al., 2019). Extract of P-Insulin, polypeptide from the fruits and seeds of $M$. balsamina rapidly reduces and normalized the blood sugar level in rats.

The leaves have been found to be highly hemolytic and hepatotoxic in rats while the fruits are regarded as toxic to various organs and tissues of rats in very high dose (Semenya and Potgieter, 2015). Thus, it is important to determine the correct dose to optimize its potential use as a medicinal plant.

\section{CONCLUSION AND FUTURE PERSPECTIVE}

The biochemical composition of $M$. charantia, M. foetida and $M$. balsamina gives them a great and interesting nutritional and medicinal value. Many of its components have singular biological activity and the synergy of them may exert interesting pharmacological properties. Several studies demonstrated that these important plants have the potential to be utilized for medicinal purposes as they exhibit anti-diabetic, anti-microbial, anthelmintic, abortifacient, anti-bacterial, anti-viral, and chemopreventive activities. These species possess a promising and innovative source of natural bioactive agents such as resins, alkaloids, flavonoids, glycosides, steroids, terpenes, cardiac glycoside, saponins, pectin, carbohydrates, amino acids, proteins, fats, fiber, chlorophyll, phosphorus, calcium, potassium, magnesium,

\section{REFERENCES}

Abegunde, M. T., Akinpelu, D. A., Omololu-Aso, J., Otusanya, O. O., and Akinlolu, J. T. (2018). Determination of Antimicrobial, Antioxidant and Phytochemical Properties of Cocos Nucifera Linn Endocarp Extract on Bacteria Associated with Human Infection. J. Pharm. Microbiol. 4.

Abidemi, O. O. (2013). Phytochemicals and Spectrophotometric Determination of Metals in Various Medicinal Plants in Nigeria. Int. J. Eng. Sci. Invent 2, 51-54.

Acquaviva, R., Di Giacomo, C., Vanella, L., Santangelo, R., Sorrenti, V., Barbagallo, I., et al. (2013). Antioxidant Activity of Extracts of Momordica Foetida Schumach. et Thonn. Molecules 18, 3241-3249. doi:10.3390/ molecules 18033241 sodium, zinc, manganese, and iron. The main biological activities of Momordica spp. has been summarized in Figure 2.

The anti-microbial, anti-parasitic and anti-ulcer activities of Momordica spp. are the mechanisms related with their inhibitory effects against gastrointestinal diseases. In addition, anti-cancer effects of several biochemicals isolated from Momordica spp. has been described. Anti-oxidant activities of Momordica spp. also prevent cancer diseases avoiding oxidative stress and oxidative damage such as lipid peroxidation. Moreover, anti-oxidants exerts anti-aging and neuroprotection effects. Additionally, the hypoglycemic activities of Momordica spp. exert an anti-diabetes effect, the hypocholesterolemic activities exerts a cardioprotective effect, and their low ratio of $\mathrm{Na}^{+} / \mathrm{K}^{+}$exerts beneficial effects against hypertension. In addition to being able to be consumed as food or supplement, clinical evidence suggests their effectiveness in managing various ailments such as dysmenorrhea, eczema, emmenagogue, galactagogue, gout, jaundice, kidney (stone), leprosy, leucorrhea, pneumonia, psoriasis, rheumatism, scabies, piles, cancer, coronary heart disease diabetes, digestion disorder, fevers, ulcers, malaria, tumors, asthma, skin infections, and hypertension.

Thus, the review suggests that the three selected crops have medicinal and herbal properties that can be used for various ailments. A better biochemical characterization is needed to better understand of medicinal properties of these plants. This review also assists to understand the commercial properties of the crop since the cultivation as commercial vegetable is currently underway. A better understand of pharmacological activities of Momortica spp. will give added value to these plants and benefit the producers.

\section{AUTHOR CONTRIBUTIONS}

All authors contributed equally to the manuscript. Conceptualization, MM, CQ, PT, TM, FM, MM, US, and RMK; validation investigation-data curation writing-all authors; review and editing, BS, AFAR, and JS-R. All the authors read and approved the final manuscript.

\section{FUNDING}

This work was supported by CONICYT PIA/APOYO CCTE AFB170007.

Aeri, V., and Raj, R. (2020). The Bitter Gourd Genome. Cham: Springer, 33-44. doi:10.1007/978-3-030-15062-4_3. Medicinal Properties of Bitter Gourd: Bioactives and Their Actions

Anilakumar, K. R., Kumar, G. P., and Ilaiyaraja, N. (2015). Nutritional, Pharmacological and Medicinal Properties of Momordica Charantia. Int. J. Food Sci. Nutr. 4, 75-83.

Anjamma, M., and Bhavani, N. L. (2018). Comparative Antibacterial and Antioxidant Activity from Root and Fruit Extracts of Momordica Charantia L . And Momordica Dioica Roxb. Int. J. S Res. Sci. Tech. 4, 1710-1716.

Aparicio, H., Hedberg, I., Bandeira, S., and Ghorbani, A. (2021). Ethnobotanical Study of Medicinal and Edible Plants Used in Nhamacoa Area, Manica Province-Mozambique. South Afr. J. Bot. 139, 318-328. doi:10.1016/j.sajb. 2021.02.029 
Aryanti, A., and Lamdayani, R. (2021). The Effect of Fraction and Active Compounds of Momordica Balsamina L. On Bacteria Salmonella Typhi Causing Salmonellosis. Ijghr 3 (1), 29-42. doi:10.37287/ijghr.v3i1.291

Asna, A. C., Joseph, J., and Joseph John, K. (2020). The Bitter Gourd Genome. Cham: Springer, 7-31. doi:10.1007/978-3-030-15062-4_2. Botanical Description of Bitter Gourd

Badhwar, R., Kaur, G., Popli, H., Yadav, D., and Buttar, H. S. (2020). "Pathophysiology of Obesity-Related Non-communicable Chronic Diseases and Advancements in Preventive Strategies," in Pathophysiology of ObesityInduced Health Complications. Editors P. S. Tappia, B. Ramjiawan, and N. S. Dhalla (Cham: Springer International Publishing)), 317-340. doi:10. 1007/978-3-030-35358-2_19

Bakare, R. I., Magbagbeola, O. A., Akinwande, A. I., and Okunowo, O. W. (2010). Nutritional and Chemical Evaluation of Momordica Charantia. J. Med. Plant Res. 4, 2189-2193.

Balouiri, M., Sadiki, M., and Ibnsouda, S. K. (2016). Methods for In Vitro Evaluating Antimicrobial Activity: A Review. J. Pharm. Anal. 6, 71-79. doi:10.1016/j.jpha.2015.11.005

Beloin, N., Gbeassor, M., Akpagana, K., Hudson, J., De Soussa, K., Koumaglo, K., et al. (2005). Ethnomedicinal Uses of Momordica Charantia (Cucurbitaceae) in Togo and Relation to its Phytochemistry and Biological Activity. J. Ethnopharmacology 96, 49-55. doi:10.1016/j.jep.2004.08.009

Birla, D. (2016). Evaluation of Antibacterial Activity of Momordica Charantia. Pharma Tutor 4, 37-40.

Bishayee, A., Ahmed, S., Brankov, N., and Perloff, M. (2011). Triterpenoids as Potential Agents for the Chemoprevention and Therapy of Breast Cancer. Front. Biosci. 16, 980-996. doi:10.2741/3730

Braca, A., Siciliano, T., D’Arrigo, M., and Germanò, M. P. (2008). Chemical Composition and Antimicrobial Activity of Momordica Charantia Seed Essential Oil. Fitoterapia 79, 123-125. doi:10.1016/j.fitote.2007.11.002

Bulbul, I. J. (2016). Determination of Antibacterial, Antifungal and Cytotoxic Activities of N-Hexane, Chloroform and Ethyl Acetate Extracts of Momordica Charantia Leaves. PharmaTutor 4, 28-33.

Cantwell, M., Nie, X., Zong, R. J., and Yamaguchi, M. (1996). Progress in New Crops. Arlington: ASHS Press, 488-495.Asian Vegetables: Selected Fruit and Leafy Types

Cao, X., Sun, Y., Lin, Y., Pan, Y., Farooq, U., Xiang, L., et al. (2018). Antiaging of Cucurbitane Glycosides from Fruits of Momordica Charantia L. Oxid Med. Cel Longev 2018, 1538632. doi:10.1155/2018/1538632

Chen, F., Huang, G., Yang, Z., and Hou, Y. (2019). Antioxidant Activity of Momordica Charantia Polysaccharide and its Derivatives. Int. J. Biol. Macromolecules 138, 673-680. doi:10.1016/j.ijbiomac.2019.07.129

Chen, J.-C., Lau, C., Chan, J., Fung, K.-P., Leung, P.-C., Liu, J.-Q., et al. (2015). The Antigluconeogenic Activity of Cucurbitacins from Momordica Charantia. Planta Med. 81, 327-332. doi:10.1055/s-0035-1545695

Chen, Q., Chan, L. L. Y., and Li, E. T. S. (2003). Bitter Melon (Momordica Charantia) Reduces Adiposity, Lowers Serum Insulin and Normalizes Glucose Tolerance in Rats Fed a High Fat Diet. J. Nutr. 133, 1088-1093. doi:10.1093/jn/ 133.4.1088

Chen, Y. F., Roan, H. Y., Lii, C. K., Huang, Y. C., and Wang, T. S. (2011). Relationship between Antioxidant and Antiglycation Ability of Saponins, Polyphenols, and Polysaccharides in Chinese Herbal Medicines Used to Treat Diabetes. J. Med. Plant Res. 5, 2322-2331.

Cohen, M., Huband, M. D., Yoder, S. L., Gage, J. W., and Roland, G. E. (1998). Bacterial Eradication by Clinafloxacin, CI-990, and Ciprofloxacin Employing MBC Test, In-Vitro Time-Kill and In-Vivo Time-Kill Studies. J. Antimicrob. Chemother. 41, 605-614. doi:10.1093/jac/41.6.605

Costa, J. G., Nascimento, E. M., Campos, A. R., and Rodrigues, F. F. (2010). Antibacterial Activity of Momordica Charantia (Curcubitaceae) Extracts and Fractions. J. Basic Clin. Pharm. 2, 45-51.

Dabeek, W. M., and Marra, M. V. (2019). Dietary Quercetin and Kaempferol: Bioavailability and Potential Cardiovascular-Related Bioactivity in Humans. Nutrients 11, 2288. doi:10.3390/nu11102288

Dandawate, P. R., Subramaniam, D., Padhye, S. B., and Anant, S. (2016). Bitter Melon: a Panacea for Inflammation and Cancer. Chin. J. Nat. medicines 14, 81-100. doi:10.1016/s1875-5364(16)60002-x

Daniel, P., Supe, U., and Roymon, M. G. (2014). A Review on Phytochemical Analysis of Momordica Charantia. Int. J. Adv. Pharm. Biol. Chem. 3, 214-220.
Dellavalle, P. D., Cabrera, A., Alem, D., Larrañaga, P., Ferreira, F., and Dalla Rizza, M. (2011). Antifungal Activity of Medicinal Plant Extracts against Phytopathogenic Fungus Alternaria Spp. Chilean J. Agric. Res. 71, 231-239. doi:10.4067/S0718-58392011000200008

Desai, S., and Tatke, P. (2015). Charantin: An Important Lead Compound from Momordica Charantia for the Treatment of Diabetes. J. Pharmacogn Phytochem. 3, 163-166.

Devyani, B., Chakravarthy, A., Mutalik, S., and Devkar, R. (2016). Determination of Antibacterial and Antifungal Properties of Rose Extract- an In Vitro Study. Int. J. Pharmacogn Phytochem. Res. 8, 1695-1697.

Dzotam, J. K., Touani, F. K., and Kuete, V. (2016). Antibacterial Activities of the Methanol Extracts of Canarium Schweinfurthii and Four Other Cameroonian Dietary Plants against Multi-Drug Resistant Gram-Negative Bacteria. Saudi J. Biol. Sci. 23, 565-570. doi:10.1016/j.sjbs.2015.06.006

Farooq, U., Pan, Y., Lin, Y., Wang, Y., Osada, H., Xiang, L., et al. (2019). Structure Characterization and Action Mechanism of an Antiaging New Compound from Gastrodia Elata Blume. Oxidative Med. Cell Longevity 2019, 5459862. doi:10.1155/2019/5459862

Fongod, A. G. N., Ngoh, L. M., and Veranso, M. C. (2014). Ethnobotany, Indigenous Knowledge and Unconscious Preservation of the Environment: An Evaluation of Indigenous Knowledge in South and Southwest Regions of Cameroon. Int. J. Biodivers. Conserv. 6, 85-99. doi:10.5897/ijbc2013.0637

Froelich, S., Onegi, B., Kakooko, A., Siems, K., Schubert, C., and Jenett-Siems, K. (2007). Plants Traditionally Used against Malaria: Phytochemical and Pharmacological Investigation of Momordica Foetida. Rev. Bras. Farmacogn. 17, 1-17. doi:10.1590/s0102-695x2007000100002

Ghosh, D. (2014). Does Bitter Melon (Momordica Charantia) Have Antibacterial Property? J. Food Process. Technol. 5, 1000345. doi:10.4172/2157-7110.1000345

Grover, J. K., and Yadav, S. P. (2004). Pharmacological Actions and Potential Uses of Momordica Charantia: a Review. J. Ethnopharmacology 93, 123-132. doi:10. 1016/j.jep.2004.03.035

Gupta, M., Sharma, S., Gautam, A., and Bhadauria, R. (2011). Momordica Charantia Linn. (Karela): Nature's Silent Healer. Int. J. Pharm. Sci. Rev. Res. $11,32-37$.

Gupta, P. (2020). "Targeted Cancer Therapy with Bioactive Foods and Their Products," in Functional Foods in Cancer Prevention and Therapy. Editor Y. Kabir (Academic Press), 33-46. doi:10.1016/b978-0-12-816151-7.00002-8

Harinantenaina, L., Tanaka, M., Takaoka, S., Oda, M., Mogami, O., Uchida, M., et al. (2006). Momordica Charantia Constituents and Antidiabetic Screening of the Isolated Major Compounds. Chem. Pharm. Bull. 54, 1017-1021. doi:10. 1248/cpb.54.1017

Hassan, L. G., and Umar, K. J. (2006). Nutritional Value of Balsam Apple (Momordica Balsamina L.) Leaves. Pak J. Nutr. 5, 525-529. doi:10.3923/pjn. 2006.522.529

Huang, H.-L., Hong, Y.-W., Wong, Y.-H., Chen, Y.-N., Chyuan, J.-H., Huang, C.-J., et al. (2008). Bitter Melon (Momordica Charantia L.) Inhibits Adipocyte Hypertrophy and Down Regulates Lipogenic Gene Expression in Adipose Tissue of Diet-Induced Obese Rats. Br. J. Nutr. 99, 230-239. doi:10.1017/ s0007114507793947

Huang, H., Chen, F., Long, R., and Huang, G. (2020). The Antioxidant Activities In Vivo of Bitter Gourd Polysaccharide. Int. J. Biol. Macromolecules 145, 141-144. doi:10.1016/j.ijbiomac.2019.12.165

Ibrahim, M. A., Saeed, B. O., Elsaid Konozy, E. H., Ahmed, S. M., and Mohamed, M. E. (2014). Isolation and Purification of Lection from Momordica Balsamina Seeds. Am. Int. J. Contem Res. 2, 4.

Ingle, K. P., Deshmukh, A. G., Padole, D. A., Dudhare, M. S., Moharil, M. P., and Khelurkar, V. C. (2017). Phytochemicals: Extraction Methods, Identification and Detection of Bioactive Compounds from Plant Extracts. J. Pharmacogn Phytochem. 6, 32-36.

Islam, S., and Jalaluddin, M. (2019). Biological Functions and Sensory Attributes of Different Skin Colored Bitter Melon (Momordica Charantia L.) Varieties. Am. J. Food Sci. H 5, 25-31.

Jabeen, U., and Khanum, A. (2017). Isolation and Characterization of Potential Food Preservative Peptide from Momordica Charantia L. Arabian J. Chem. 10, S3982-S3989. doi:10.1016/j.arabjc.2014.06.009

Jia, S., Shen, M., Zhang, F., and Xie, J. (2017). Recent Advances in Momordica Charantia: Functional Components and Biological Activities. Ijms 18, 2555. doi:10.3390/ijms18122555 
Jiang, Y., Peng, X.-R., Yu, M.-Y., Wan, L.-S., Zhu, G.-L., Zhao, G.-T., et al. (2016). Cucurbitane-type Triterpenoids from the Aerial Parts of Momordica Charantia L. Phytochemistry Lett. 16, 164-168. doi:10.1016/j.phytol.2016.04.007

Joseph, B., and Jini, D. (2013). Antidiabetic Effects of Momordica Charantia (Bitter Melon) and its Medicinal Potency. Asian Pac. J. Trop. Dis. 3, 93-102. doi:10. 1016/s2222-1808(13)60052-3

Ju, Y. H., Clausen, L. M., Allred, K. F., Almada, A. L., and Helferich, W. G. (2004). $\beta$-Sitosterol, $\beta$-Sitosterol Glucoside, and a Mixture of $\beta$-Sitosterol and $\beta$-Sitosterol Glucoside Modulate the Growth of Estrogen-Responsive Breast Cancer Cells In Vitro and in Ovariectomized Athymic Mice. J. Nutr. 134, 1145-1151. doi:10.1093/jn/134.5.1145

Kandakumar, S., and Manju, D. V. (2017). Pharmacological Applications of Isorhamnetin: A Short Review. Ijtsrd Volume-1, 672-678. doi:10.31142/ ijtsrd 2202

Kangsamaksin, T., Chaithongyot, S., Wootthichairangsan, C., Hanchaina, R., Tangshewinsirikul, C., and Svasti, J. (2017). Lupeol and Stigmasterol Suppress Tumor Angiogenesis and Inhibit Cholangiocarcinoma Growth in Mice via Downregulation of Tumor Necrosis Factor-Alpha. PLoS One 12, e0189628. doi:10.1371/journal.pone.0189628

Kaur, N., Chaudhary, J., Jain, A., and Kishore, L. (2011). Stigmasterol: a Comprehensive Review. J. Pharm. Sci. Res. 2, 2259.

Kesari, P., Pratap, S., Dhankhar, P., Dalal, V., Mishra, M., Singh, P. K., et al. (2020). Structural Characterization and In-Silico Analysis of Momordica Charantia 7S Globulin for Stability and ACE Inhibition. Scientific Rep. 10, 1160. doi:10.1038/ s41598-020-58138-9

Khadijeh, S., Elham, J., Mahboubeh, M., and Mehdi, H. (2019). Study the Antimicrobial Effects of Momordica Charantia on Pathogenic Bacteria. J. Med. Bacteriol. 8, 1-7.

Khalid, Z., Hassan, S. M., Mughal, S. S., Hassan, S. K., and Hassan, H. (2021). Phenolic Profile and Biological Properties of Momordica Charantia. Chem. Biomol. Eng. 6 (1), 17-29. doi:10.11648/j.cbe.20210601.13

Khanna, P. (2004). Protein/polypeptide-k Obtained from Momordica Charantia and a Process for the Extraction Thereof. U.S. Patent 6, 831. 162.

Khoza, B. S., Dubery, I. A., Byth-Illing, H.-A., Steenkamp, P. A., Chimuka, L., and Madala, N. E. (2016). Optimization of Pressurized Hot Water Extraction of Flavonoids from Momordica Foetida Using UHPLC-qTOF-MS and Multivariate Chemometric Approaches. Food Anal. Methods 9, 1480-1489. doi:10.1007/s12161-015-0302-8

Kim, K. B., Lee, S., Kang, I., and Kim, J. H. (2018). Momordica Charantia Ethanol Extract Attenuates $\mathrm{H}(2) \mathrm{O}(2)$-Induced Cell Death by its Antioxidant and Antiapoptotic Properties in Human Neuroblastoma SK-N-MC Cells. Nutrients 10. doi:10.3390/nu10101368

Koneri, R., Balaraman, R., and Saraswati, C. D. (2006). Antiovulatory and Abortifacient Potential of the Ethanolic Extract of Roots of Momordica Cymbalaria Fenzl in Rats. Indian J. Pharmacol. 38. doi:10.4103/0253-7613. 24616

Krawinkel, M. B., and Keding, G. B. (2006). Bitter Gourd (Momordica Charantia): A Dietary Approach to Hyperglycemia. Nutr. Rev. 64, 331-337. doi:10.1111/j. 1753-4887.2006.tb00217.x

Kuete, V., Poumale, H. M. P., Guedem, A. N., Shiono, Y., Randrianasolo, R., and Ngadjui, B. T. (2010). Antimycobacterial, Antibacterial and Antifungal Activities of the Methanol Extract and Compounds from Thecacoris Annobonae (Euphorbiaceae). South Afr. J. Bot. 76, 536-542. doi:10.1016/j. sajb.2010.04.003

Kulkarni, P., Lohidasan, S., and Mahadik, K. (2021). Isolation, Characterisation and Investigation of In Vitro Antidiabetic and Antioxidant Activity of Phytoconstituents from Fruit of Momordica Charantia Linn. Nat. Product. Res. 35 (6), 1035-1037. doi:10.1080/14786419.2019.1613400

Kumar, K. S., and Bhowmik, D. (2010). Traditional Medicinal Uses and Therapeutic Benefits of Momordica Charantia Linn. Int. J. Pharm. Sci. Rev. Res. 4, 23-28. doi:10.4103/0973-7847.65327

Kumar, R., Balaji, S., Uma, T. S., and Sehgal, P. K. (2009). Fruit Extracts of Momordica Charantia Potentiate Glucose Uptake and Up-Regulate Glut-4, PPAR $\gamma$ and PI3K. J. Ethnopharmacology 126, 533-537. doi:10.1016/j.jep.2009. 08.048

Lee, S. H., Jeong, Y. S., Song, J., Hwang, K.-A., Noh, G. M., and Hwang, I. G. (2017). Phenolic Acid, Carotenoid Composition, and Antioxidant Activity of Bitter
Melon (Momordica Charantia L.) at Different Maturation Stages. Int. J. Food Properties 20, S3078-S3087. doi:10.1080/10942912.2016.1237961

Lee, Y. H., Yoon, S.-Y., Baek, J., Kim, S. J., Yu, J. S., Kang, H., et al. (2021). Metabolite Profile of Cucurbitane-type Triterpenoids of Bitter Melon (Fruit of Momordica Charantia) and Their Inhibitory Activity against Protein Tyrosine Phosphatases Relevant to Insulin Resistance. J. Agric. Food Chem. 69 (6), 1816-1830. doi:10.1021/acs.jafc.0c06085

Leelaprakash, G., Rose, J. C., Gowtham, B. M., Javvaji, P. K., and Prasad, S. A (2011). In vitro antimicrobial and Antioxidant Activity of Momordica Charantia Leaves. Pharmacophore 2, 244-252.

Leung, L., Birtwhistle, R., Kotecha, J., Hannah, S., and Cuthbertson, S. (2009). Antidiabetic and Hypoglycaemic Effects of Momordica Charantia (Bitter Melon): a Mini Review. Br. J. Nutr. 102, 1703-1708. doi:10.1017/s0007114509992054

Li, Q. Y., Liang, H., Wang, B., and Zhao, Y. Y. (2009). [Chemical Constituents of Momordica Charantia L]. Yao Xue Xue Bao 44, 1014-1018.

Li, W., Lin, Z., Yang, C., Wang, Y., and Qiao, Y. (2015).Study on the Chemical Constituents of Momordica Charantia L. Leaves Andmethod for Their Quantitative Determination. Biomed. Research-tokyo, 26, 415-419.

Lii, C.-K., Chen, H.-W., Yun, W.-T., and Liu, K.-L. (2009). Suppressive Effects of Wild Bitter Gourd (Momordica Charantia Linn. Var. Abbreviata ser.) Fruit Extracts on Inflammatory Responses in RAW 264.7 Macrophages. J. Ethnopharmacology 122, 227-233. doi:10.1016/j.jep.2009.01.028

Limtrakul, P., Pitchakarn, P., and Suzuki, S. (2013). Kuguacin J, a Triterpenoid from Momordica Charantia Linn: A Comprehensive Review of Anticarcinogenic Properties. Carcinogenesis 275. doi:10.5772/55532

Liu, J.-Q., Chen, J.-C., Wang, C.-F., Qiu, M.-H., Liu, Z., Gong, J., et al. (20092021). New Cucurbitane Triterpenoids and Steroidal Glycoside from Momordica charantiaThe Effect of Momordica Charantia in the Treatment of Diabetes Mellitus: A Review. Moleculesevid Based Complement. Altern Med 142021, 4804-4813. doi:10.3390/molecules14124804

Lu, Y.-L., Liu, Y. H., Liang, W. L., Chuang, J. H., Cheng, K.-T., Liang, H. J., et al. (2011). Antibacterial and Cytotoxic Activities of Different Wild Bitter Gourd Cultivars (Momordica Charantia L. Var. Abbreviata Seringe). Bot. Stud. 52, 427-434.

Ludidi, A., Baloyi, M. C., Khathi, A., Sibiya, N. H., and Ngubane, P. S. (2019). The Effects of Momordica Balsamina Methanolic Extract on Haematological Function in Streptozotocin-Induced Diabetic Rats: Effects on Selected Markers. Biomed. Pharmacother. 116, 108925. doi:10.1016/j.biopha.2019. 108925

Ma, J., Krynitsky, A. J., Grundel, E., and Rader, J. I. (2012). Quantitative Determination of Cucurbitane-type Triterpenes and Triterpene Glycosides in Dietary Supplements Containing Bitter Melon (Momordica Charantia) by HPLC-MS/MS. J. AOAC Int. 95, 1597-1608. doi:10.5740/jaoacint.11-511

Mada, S. B., Garba, A., Mohammed, H. a. A., Muhammad, A., and Olagunju, A. (2013). Antimicrobial Activity and Phytochemical Screening of Aqueous and Ethanol Extracts of Momordica Charantia L. Leaves. J. Med. Plants Res. 7, 579-586.

Madala, N. E., Tugizimana, F., and Steenkamp, P. A. (2014). Development and Optimization of an UPLC-QTOF-MS/MS Method Based on an In-Source Collision Induced Dissociation Approach for Comprehensive Discrimination of Chlorogenic Acids Isomers from Momordica Plant Species. J. Anal. Methods Chem. 2014, 650879. doi:10.1155/2014/6508792014

Madala, N. E., Piater, L., Dubery, I., and Steenkamp, P. (2016). Distribution Patterns of Flavonoids from Three Momordica Species by Ultra-high Performance Liquid Chromatography Quadrupole Time of Flight Mass Spectrometry: a Metabolomic Profiling Approach. Revista Brasileira de Farmacognosia 26, 507-513. doi:10.1016/j.bjp.2016.03.009

Malik, J. A., Iqbal, S., Biswas, J., Riaz, U., and Datta, S. (2021). Antidiabetic Property of Aloe Vera (Aloe Barbadensis) and Bitter Melon (Momordica Charantia). Med. Aromatic Plants: Healthc. Ind. Appl., 257-269. doi:10.1007/978-3-03058975-2_10

Marquis, V., Adanlawo, T., and Olaniyi, A. (1977). The Effect of Foetidin from Momordica Foetida on Blood Glucose Level of Albino Rats. Planta Med. 31, 367-374. doi:10.1055/s-0028-1097545

Moher, D., Liberati, A., Tetzlaff, J., and Altman, D. G. (2009). Preferred Reporting Items for Systematic Reviews and Meta-Analyses: the PRISMA Statement. Plos Med. 6, e1000097. doi:10.1371/journal.pmed.1000097 
Molehin, O. R., and Adefegha, S. A. (2014). Comparative Study of the Aqueous and Ethanolic Extract of Momordica Foetida on the Phenolic Content and Antioxidant Properties. Int. Food Res. J. 21, 401.

Mostafa, A. A., Al-Askar, A. A., Almaary, K. S., Dawoud, T. M., Sholkamy, E. N., and Bakri, M. M. (2018). Antimicrobial Activity of Some Plant Extracts against Bacterial Strains Causing Food Poisoning Diseases. Saudi J. Biol. Sci. 25, 361-366. doi:10.1016/j.sjbs.2017.02.004

Mulholland, D. A., Sewram, V., Osborne, R., Pegel, K. H., and Connolly, J. D. (1997). Cucurbitane Triterpenoids from the Leaves of Momordica Foetida. Phytochemistry 45, 391-395. doi:10.1016/s0031-9422(96)00814-x

Mwambete, K. D. (2009). The In Vitro Antimicrobial Activity of Fruit and Leaf Crude Extracts of Momordica Charantia: a Tanzania Medicinal Plant. Afr. Health Sci. 9, 34-39.

Ndam, L., Mih, A., Fongod, A., Tening, A. S., Tonjock, R. K., Enang, J., et al. (2014). Phytochemical Screening of the Bioactive Compounds in Twenty (20) Cameroonian Medicinal Plants. Int. J. Curr. Microbiol. App Sci. 3, 768-778.

Nerurkar, P. V., Lee, Y. K., and Nerurkar, V. R. (2010). Momordica Charantia (Bitter Melon) Inhibits Primary Human Adipocyte Differentiation by Modulating Adipogenic Genes. BMC Complement. Altern. Med. 10, 34. doi:10.1186/1472-6882-10-34

Nitu, S., and Patidar, K. C. (2017). Evaluation of Antimicrobial Activity Determination and Phytochemical Investigation in Selected Plants. Int. J. Pharmacogn Phytochem. Res. 9, 1429-1434. doi:10.25258/phyto.v9i11.11187

Nyam, K. L., Tan, C. P., Lai, O. M., Long, K., and Che Man, Y. B. (2009). Physicochemical Properties and Bioactive Compounds of Selected Seed Oils. LWT - Food Sci. Tech. 42, 1396-1403. doi:10.1016/j.lwt.2009.03.006

Odeleye, O. M., Oyedeji, O. A., and Shode, F. O. (2009). Constituents of Momordica Foetida and Evaluation of Their Antimicrobial Activity. Planta Med. 75, 24. doi:10.1055/s-2009-1216462

Odusote, M. O., and Awaraka, C. N. (2004). Momordica Foetida (Cucurbitacea) A Potential Laxative Granule/Capsule. Nig Q. J. Hosp. Med. 14, 189-194. doi:10. 4314/nqjhm.v14i2.12719

Okabe, H., Miyahara, Y., and Yamauchi, T. (1982). Studies on the Constituents of Momordica Charantia L. IV. Characterization of the New Cucurbitacin Glycosides of the Immature Fruits. (2). Structures of the Bitter Glycosides, Momordicosides K and L. Chem. Pharm. Bull. 30, 4334-4340. doi:10.1248/cpb. 30.4334

Olaniyi, A. A., and Marquis, V. O. (1975). Phytochemical and Preliminary Pharmacological Investigation of the Alkaloid Obtained from Momordica Foetida. J. Pharm. 6, 117-119.

Oloyede, O. I., and Aluko, O. M. (2012). Determination of Antioxidant Potential of Momordica Foetida Leaf Extract on Tissue Homogenate. Sci. J. Clin. Med. Trial 2012, 1-4. doi:10.7237/sjmct/225

Orhan, D. D., Özçelik, B., Özgen, S., and Ergun, F. (2010). Antibacterial, Antifungal, and Antiviral Activities of Some Flavonoids. Microbiol. Res. 165, 496-504. doi:10.1016/j.micres.2009.09.002

Oronje, M. L., Hagen, M., Gikungu, M., Kasina, M., and Kraemer, M. (2012). Pollinator Diversity, Behaviour and Limitation on Yield of Karela (Momordica Charantia L. Cucurbitaceae) in Western Kenya. Afr. J. Agric. Res. 7, 1629-1638. doi:10.5897/AJAR11.725

Ozusaglam, M. A., and Karakoca, K. (2013). Antimicrobial and Antioxidant Activities of Momordica Charantia from Turkey. Afr. J. Biotechnol. 12 (13), 1548-1558. doi:10.5897/AJB2012.2932

Palada, M. C., and Chang, L. C. (2003). Suggested Cultural Practices for Bitter Gourd. AVRDC Int. Cooperators' Guide, 3-15.

Pari, M., Arjunan, N., Subramani, U., Ramasamy, V., Kadarkarai, M., and Chinnathambi, V. (2020). Water Purification and Larvicidal Activity of Seed Extract, Momordica Charantia. GSC Adv. Res. Rev. 2, 1-9. doi:10.30574/gscarr. 2020.2.1.0001

Patel, S., Patel, T., Parmar, K., Bhatt, Y., Patel, Y., and Patel, N. M. (2010). Isolation, Characterization and Antimicrobial Activity of Charantin from Momordica Charantia Linn. Fruit. Int. J. Drug Dev. Res. 2, 629-634. doi:10.4103/0974-8490.65509

Patil, S. S., and Rathod, V. K. (2020). Synergistic Effect of Ultrasound and Three Phase Partitioning for the Extraction of Curcuminoids from Curcuma Longa and its Bioactivity Profile. Process Biochem. 93, 85-93. doi:10.1016/j.procbio. 2020.02.031

Pauliuc, I., and Botau, D. (2013). Antibacterial Activity of Momordica Charantia L. Gemmotherapic Extract. Scientific Bull. Ser. F Biotechnologies 17, 57-60.
Perera, W. H., Shivanagoudra, S. R., Pérez, J. L., Kim, D. M., Sun, Y. K., et al. (2021). Anti-Inflammatory, Antidiabetic Properties and In Silico Modeling of Cucurbitane-type Triterpene Glycosides from Fruits of an Indian Cultivar of Momordica Charantia L. Molecules 26, 1038. doi:10.3390/ molecules 26041038

Perumal, V., Khatib, A., Uddin Ahmed, Q., Fathamah Uzir, B., Abas, F., Murugesu, S., et al. (2021). Antioxidants Profile of Momordica Charantia Fruit Extract Analyzed Using LC-MS-QTOF-based Metabolomics. Food Chem. Mol. Sci. 2, 100012. doi:10.1016/j.fochms.2021.100012

Pinar, M., Rico, M., Pascual, C., and Fernández, B. (1983). Foetidin, an 8,9-Seco-17Nor-Kaurane Diterpenoid from Elaeoselinum Foetidum. Phytochemistry 22, 2775-2777. doi:10.1016/s0031-9422(00)97694-5

Pirillo, A., Verotta, L., Gariboldi, P., Torregiani, E., and Bombardelli, E. (1995). Constituents of Nothapodytes Foetida. J. Chem. Soc. Perkin Trans. 1 1, 583-587. doi:10.1039/p19950000583

Poyraz, L. E., and Derdovski, C. (2016). Morpho-anatomical Investigations on Momordica Charantia L. (Cucurbitaceae). Anadolu Univ. J. Sci. Tech. - C. Life Sci. Biotechnol. 5, 23-30. doi:10.18036/btdc.78679

Puškárová, A., Bučková, M., Kraková, L., Pangallo, D., and Kozics, K. (2017). The Antibacterial and Antifungal Activity of Six Essential Oils and Their Cyto/ genotoxicity to Human HEL 12469 Cells. Sci. Rep. 7, 8211. doi:10.1038/s41598017-08673-9

Rahmatullah, M., Azam, M. N., Khatun, Z., Seraj, S., Islam, F., Rahman, M. A., et al. (2012). Medicinal Plants Used for Treatment of Diabetes by the Marakh Sect of the Garo Tribe Living in Mymensingh District, Bangladesh. Afr. J. Tradit Complement. Altern. Med. 9, 380-385. doi:10.4314/ajtcam.v9i3.12

Raina, K., Kumar, D., and Agarwal, R. (2016). Promise of Bitter Melon (Momordica Charantia) Bioactives in Cancer Prevention and Therapy. Semin. Cancer Biol. 40-41, 116-129. doi:10.1016/j.semcancer.2016.07.002

Ramalhete, C., Molnár, J., Mulhovo, S., Rosário, V. E., and Ferreira, M.-J. U. (2009). New Potent P-Glycoprotein Modulators with the Cucurbitane Scaffold and Their Synergistic Interaction with Doxorubicin on Resistant Cancer Cells. Bioorg. Med. Chem. 17, 6942-6951. doi:10.1016/j.bmc. 2009.08.020

Ramalhete, C., Mulhovo, S., Molnar, J., and Ferreira, M.-J. U. (2016). Triterpenoids from Momordica Balsamina: Reversal of ABCB1-Mediated Multidrug Resistance. Bioorg. Med. Chem. 24, 5061-5067. doi:10.1016/j. bmc.2016.08.022

Ramalhete, C., Spengler, G., Martins, A., Martins, M., Viveiros, M., Mulhovo, S., et al. (2011). Inhibition of Efflux Pumps in Meticillin-Resistant Staphylococcus aureus and Enterococcus faecalis Resistant Strains by Triterpenoids from Momordica Balsamina. Int. J. Antimicrob. Agents 37, 70-74. doi:10.1016/j. ijantimicag.2010.09.011

Rolnik, A., and Olas, B. (2020). Vegetables from the Cucurbitaceae Family and Their Products: Positive Effect on Human Health. Nutrition 78, 110788. doi:10. 1016/j.nut.2020.110788

Roškar, R., and Lušin, T. T. (2012). Analytical Methods for Quantification of Drug Metabolites in Biological Samples. Chromatography-The Most Versatile Method Chem. Anal., 79-126. doi:10.5772/51676

Saad, D. Y., Soliman, M. M., Baiomy, A. A., Yassin, M. H., and El-Sawy, H. B. (2017). Effects of Karela (Bitter Melon; Momordica Charantia) on Genes of Lipids and Carbohydrates Metabolism in Experimental Hypercholesterolemia: Biochemical, Molecular and Histopathological Study. BMC Complement. Altern. Med. 17, 319. doi:10.1186/s12906-017-1833-x

Santhosh Kumar, J. U., Ramakrishan, M., Seethapathy, G. S., Krishna, V., Uma Shaanker, R., and Ravikanth, G. (2020). DNA Barcoding of Momordica Species and Assessment of Adulteration in Momordica Herbal Products, an Anti-diabetic Drug. Plant Gene 22, 100227. doi:10.1016/j.plgene.2020.100227

Santos, K. K. A., Matias, E. F. F., Sobral-Souza, C. E., Tintino, S. R., Morais-Braga, M. F. B., Guedes, G. M. M., et al. (2012). Trypanocide, Cytotoxic, and Antifungal Activities ofMomordica Charantia. Pharm. Biol. 50, 162-166. doi:10.3109/13880209.2011.581672

Sathasivam, R., Park, C. H., Yeo, H. J., Park, Y. E., Kim, J. K., and Park, S. U. (2021). Analysis of Triterpenoids, Carotenoids, and Phenylpropanoids in the Flowers, Leaves, Roots, and Stems of White Bitter Melon (Cucurbitaceae, Momordica Charantia). Trop. J. Pharm. Res. 20 (1), 155-160. doi:10.4314/tjpr.v20i1.22

Schrot, J., Weng, A., and Melzig, M. (2015). Ribosome-inactivating and Related Proteins. Toxins 7, 1556-1615. doi:10.3390/toxins7051556 
Scorzoni, L., Benaducci, T., Almeida, A. M. F., Silva, D. H. S., Bolzani, V. d. S., and Gianinni, M. J. S. M. (2007). The Use of Standard Methodology for Determination of Antifungal Activity of Natural Products against Medical Yeasts Candida Sp and Cryptococcus Sp. Braz. J. Microbiol. 38, 391-397. doi:10. 1590/s1517-83822007000300001

Semenya, S. S., and Potgieter, M. J. (2015). Kirkia Wilmsii : A Bapedi Treatment for Hypertension. South Afr. J. Bot. 100, 228-232. doi:10.1016/j.sajb.2015.05.029

Sen, A., and Batra, A. (2012). Evaluation of Antimicrobial Activity of Different Solvent Extracts of Medicinal Plant: Melia Azedarach L. Int. J. Curr. Pharm. Res. 4.

Shah, S., Hussain, M., Aslam, M., and Rivera, G. (2014). Natural Products; Pharmacological Importance of Family Cucurbitaceae: a Brief Review. Mrmc 14, 694-705. doi:10.2174/1389557514666140820113055

Souda, S., George, S., Mannathoko, N., Goercke, I., and Chabaesele, K. (2018). Antioxidant and Antibacterial Activity of Methanol Extract of Momordica Balsamina. IRA-JAS 10, 7-17. doi:10.21013/jas.v10.n2.p1

Spengler, G., Ramalhete, C., Martins, M., Martins, A., Serly, J., Viveiros, M., et al. (2009). Evaluation of Cucurbitane-type Triterpenoids from Momordica Balsamina on P-Glycoprotein (ABCB1) by Flow Cytometry and Real-Time Fluorometry. Anticancer Res. 29, 3989-3993.

Talukdar, S. N., and Hossain, M. N. (2014). Phytochemical, Phytotherapeutical and Pharmacological Study of Momordica Dioica. Evid. Based Complement. Alternat Med. 2014, 806082. doi:10.1155/2014/806082

Tan, C., Zuo, J., Yi, X., Wang, P., Luo, C., Hu, Y., et al. (2015a). Phenolic Constituents from Sarcopyramis Nepalensis and Their a-Glucosidase Inhibitory Activity. Afr. J. Trad. Compl. Alt. Med. 12, 156-160. doi:10.4314/ajtcam.v12i3.20

Tan, E. S., Abdullah, A., and Kassim, N. K. (2015b). Extraction of Steroidal Glycoside from Small-Typed Bitter Gourd (Momordica Charantia L.). J. Chem. Pharm. Res. 7, 870-878.

Tan, M.-J., Ye, J.-M., Turner, N., Hohnen-Behrens, C., Ke, C.-Q., Tang, C.-P., et al. (2008). Antidiabetic Activities of Triterpenoids Isolated from Bitter Melon Associated with Activation of the AMPK Pathway. Chem. Biol. 15, 263-273. doi:10.1016/j.chembiol.2008.01.013

Tansey, J., Sztalryd, C., Hlavin, E., Kimmel, A., and Londos, C. (2004). The Central Role of Perilipin a in Lipid Metabolism and Adipocyte Lipolysis. IUBMB Life (International Union Biochem. Mol. Biol. Life) 56, 379-385. doi:10.1080/15216540400009968

Thakur, G., Bag, M., Sanodiya, B., Bhadauriya, P., Debnath, M., Prasad, G., et al. (2009). Momordica Balsamina: a Medicinal and Neutraceutical Plant for Health Care Management. Cpb 10, 667-682. doi:10.2174/138920109789542066

Tokhtar, V. K., and Doan, H. G. (2014). Ecological and Biological Features of Tropical Species of the Genus Momordica (Cucurbitaceae) Introduced under the Conditions of Belgorod Region (Russia). Russia: Belgorod State National Research University Pobeda Street, 85, Belgorod, 308015.

Trakoon-Osot, W., Sotanaphun, U., Phanachet, P., Porasuphatana, S., Udomsubpayakul, U., and Komindr, S. (2013). Pilot Study: Hypoglycemic and Antiglycation Activities of Bitter Melon (Momordica Charantia L.) in Type 2 Diabetic Patients. J. Pharm. Res. 6, 859-864. doi:10.1016/j.jopr.2013.08.007

Venugopal, D., and Dhanasekaran, S. (2021). Bitter Gourd (Momordica Charantia) as an Emerging Therapeutic Agent: Modulating Metabolic Regulation and Cell
Signaling Cascade. Stud. Nat. Prod. Chem. 67, 221-268. doi:10.1016/B978-0-12819483-6.00007-2

Waako, P. J., Gumede, B., Smith, P., and Folb, P. I. (2005). The In Vitro and In Vivo Antimalarial Activity of Cardiospermum Halicacabum L. And Momordica Foetida Schumch. Et Thonn. J. Ethnopharmacology 99, 137-143. doi:10. 1016/j.jep.2005.02.017

Wang, S., Zheng, Y., Xiang, F., Li, S., and Yang, G. (2016). Antifungal Activity of Momordica Charantia Seed Extracts toward the Pathogenic Fungus Fusarium Solani L. J. Food Drug Anal. 24, 881-887. doi:10.1016/j.jfda.2016.03.006

Wang, X., Sun, W., Cao, J., Qu, H., Bi, X., and Zhao, Y. (2012). Structures of New Triterpenoids and Cytotoxicity Activities of the Isolated Major Compounds from the Fruit of Momordica Charantia L. J. Agric. Food Chem. 60, 3927-3933. doi:10.1021/jf204208y

Wardani, B. P. N., Rifa'i, M., and Rahayu, S. (2021). Bitter Melon (Momordica charantia L.) and Star fruit (Averrhoa bilimbi L.) on Proinflammatory Cytokines Produced by Hyperglycemic Mice Model. J. Exp. Life Sci. 10 (2), 89-93.

Wardhani, T., Abadi, A. L., Himawan, T., and Am, A. (2015). Composition of Water Extract from Wild Bitter Gourd (Momordica Charantia L.) Fruit for Application as Antifeedant and Mortality Test on Armyworm Larvae (Spodoptera Litura Fab.). J. Biol. Life Sci. 6. doi:10.5296/jbls.v6i2.8084

Wikaningtyas, P., and Sukandar, E. Y. (2016). The Antibacterial Activity of Selected Plants towards Resistant Bacteria Isolated from Clinical Specimens. Asian Pac. J. Trop. Biomed. 6, 16-19. doi:10.1016/j.apjtb.2015.08.003

Yoshime, L. T., De Melo, I. L. P., Sattler, J. a. G., De Carvalho, E. B. T., and ManciniFilho, J. (2016). Bitter Gourd (Momordica Charantia L.) Seed Oil as a Naturally Rich Source of Bioactive Compounds for Nutraceutical Purposes. Nutrire 41, 12. doi:10.1186/s41110-016-0013-y

Yue, J., Sun, Y., Xu, J., Zhang, X., and Zhao, Y. (2020). Four New Cucurbitane-type Triterpenes from Momordica Charantia L. With Their Cytotoxic Activities and Protective Effects on H2O2-Damaged Pancreatic Cells. J. Nat. Med. 74, 34-40. doi:10.1007/s11418-01901336-1

Yuwai, K. E., Rao, K. S., Kaluwin, C., Jones, G. P., and Rivett, D. E. (1991). Chemical Composition of Momordica Charantia L. Fruits. J. Agric. Food Chem. 39, 1762-1763. doi:10.1021/jf00010a013

Conflict of Interest: The authors declare that the research was conducted in the absence of any commercial or financial relationships that could be construed as a potential conflict of interest.

Copyright (C) 2021 Muronga, Quispe, Tshikhudo, Msagati, Mudau, Martorell, Salehi, Abdull Razis, Sunusi, Kamal and Sharifi-Rad. This is an open-access article distributed under the terms of the Creative Commons Attribution License (CC $B Y)$. The use, distribution or reproduction in other forums is permitted, provided the original author(s) and the copyright owner(s) are credited and that the original publication in this journal is cited, in accordance with accepted academic practice. No use, distribution or reproduction is permitted which does not comply with these terms. 